\title{
Conodont association of the Bashkirian-Moscovian boundary interval of the Donets Basin, Ukraine
}

\author{
Tamara I. NEMYROVSKA ${ }^{1^{*}} \&$ Keyi $H U^{2}$
}

\author{
${ }^{1}$ Institute of Geological Sciences, National Academy of Sciences of Ukraine, 55-b O, Gonchar St., 01601 Kiev, Ukraine; \\ tamaranemyrovska@gmail.com \\ ${ }^{2}$ Centre for Research and Education on Biological Evolution and Environment, Nanjing University, 163 Xianlin Rd., 210023 \\ Nanjing, PR China; kyhu@nju.edu.cn \\ * Corresponding author
}

Nemyrovska, T.I. \& Hu, K. 2018. Conodont association of the Bashkirian-Moscovian boundary interval of the Donets Basin, Ukraine. [Asociaciones de conodontos de la transición Bashkiriense-Moscoviense de la Cuenca del Donets, Ucrania]. Spanish Journal of Palaeontology, 33 (1), 105-128.

\begin{abstract}
Ten sections spanning the Bashkirian-Moscovian boundary interval were studied in the Donets Basin. Six of them contain most representative conodont and foraminifer associations. In this paper we focused on three the most complete sections that include stratigraphically important conodont species, which belong to the Declinognathodus, Idiognathoides, Idiognathodus, Neognathodus, "Streptognathodus", Mesogondolella and Diplognathodus genera. The majority of those species are widely distributed, which makes the correlation to other areas reliable. Two biotic events in conodont evolution were discovered in these sections. Two conodont lineages established here are considered as potential markers for the definition of the lower boundary of the Global Moscovian Stage: D. marginodosus - D. donetzianus and Id. sulcatus sulcatus - Id. postsulcatus. The conodonts $D$. donetzianus and Id. postsulcatus, both proposed before as potential markers for the definition of the GSSP at the Bashkirian-Moscovian boundary, are described and compared to those from the other areas. The entry of $D$. donetzianus is updated and confirmed to the top of the limestone $\mathrm{K}_{1}$ in both sections, the Zolota Valley and the Malo-Mykolaivka
\end{abstract}

\section{RESUMEN}

En este trabajo se estudian diez secciones que abarcan el intervalo del límite Bashkiriense-Moscoviense en la Cuenca de Donets. Seis de estas secciones contienen las asociaciones más representativas de conodontos y foraminíferos. En este artículo nos centramos en tres de las secciones más completas y que incluyen especies de conodontos estratigráficamente importantes pertenecientes a los géneros Declinognathodus, Idiognathoides, Idiognathodus, Neognathodus, "Streptognathodus», Mesogondolella y Diplognathodus. La mayoría de las especies están ampliamente distribuidas, lo que hace que la correlación con otras áreas sea fiable. En estas secciones se descubrieron dos eventos bióticos en la evolución de los conodontos. Dos linajes de conodontos establecidos aquí se consideran marcadores potenciales para la definición del límite inferior de la Etapa Global Moscoviense: D. marginodosus - D. donetzianus y Id. sulcatus sulcatus - Id. postsulcatus. Los conodontos D. donetzianus y Id. postsulcatus, ambos propuestos anteriormente como posibles marcadores para la definición del GSSP en el límite entre Bashkiriense y Moscoviense, se describen y comparan con los de las otras áreas. La entrada de D. donetzianus se 
sections. The other proposals for the definition of the lower Moscovian boundary by conodonts are discussed. Three conodont zones characterize the Bashkirian-Moscovian boundary interval. These are, in ascending order: the $I d$. tuberculatus - Id. fossatus Zone and D. marginodosus Zone from the upper Bashkirian, and D. donetzianus Zone from the lower Moscovian. They were recently described and shortly given in this paper.

Keywords: Conodonts, Bashkirian-Moscovian, zonation, lineage, evolution event.

\section{INTRODUCTION}

The position of the boundary between the Global Bashkirian and Moscovian stages (Lower-Middle Pennsylvanian boundary) or GSSP for the lower boundary of the Moscovian Stage is not still established and remains one of the main tasks of the International Subcommission on the Carboniferous Stratigraphy (Alekseev \& Task Group, 2017).

The Bashkirian Stage is the lowest series of the Pennsylvanian Subsystem. It was first established as "the Bashkirian beds" by Semikhatova (1934) at the Askyn section, South Urals. These beds were characterized by a specific group of brachiopods called "coarse ribbed Choristites". Later, these beds were rank as a stage (Semikhatova, 1941).

The Moscovian Stage was established by S.N. Nikitin in 1890 in the Moscow Syneclise, Russia, as equivalent to the middle series of the Carboniferous (Nikitin, 1890). Nikitin thought that the Moscovian Stage of the Moscow Syneclise corresponds to the Middle Carboniferous of the Urals. For a long time, the title "Moscovian" has been related to the entire Middle Carboniferous. When the Bashkirian Stage was established, the Middle Carboniferous was not called "the Moscovian" any longer.

The stratotype of the Moscovian Stage is located in the Moscow Syneclise, and the Bashkirian stratotype in Urals. There is quite a distance between the two type areas. Moreover, the basal beds of the Moscovian Stage in its type area are represented by terrestrial deposits and thus do not contain marine fossils. Furthermore, an unconformity eliminates marine Bashkirian deposits and fossils in the Moscow Syneclise, including foraminifers that were used traditionally for definition of the Bashkirian-Moscovian boundary position and for intrastage correlations. As a result, the lower boundary of the Moscovian Stage is difficult to correlate with the other areas, especially with the Bashkirian stratotype. The latter is completely carbonate section but its fauna in the Bashkirian-Moscovian transition is rather specific, and the correlation is not easy. actualiza y confirma en la parte superior de la caliza $\mathrm{K}_{1}$ en ambas secciones: las secciones del Valle de Zolota y de Malo-Mykolaivka. Se discuten las otras propuestas para la definición del límite inferior Moscoviense con conodontos. Tres zonas de conodontos caracterizan el intervalo límite entre Bashkiriense y Moscoviense. Estos son, en orden ascendente: la Zona Id. tuberculatus - Id. fossatus y la D. marginodosus para el Bashkiriense superior, y la Zona $D$. donetzianus para el Moscoviense inferior. Han sido descritos recientemente y en este trabajo sólo se reseñan brevemente.

Palabras clave: Conodontos, Bashkiriense-Moscoviense, zonación, linaje, evento de evolución.
The Carboniferous of the Donets Basin, Ukraine, is one of the best successions to attempt to solve the problem of the Bashkirian-Moscovian boundary correlation. The Carboniferous of the Donets Basin is a thick terrigenous strata of interbedded argillites, siltstones and sandstones with thin limestone interlayers and coal seams. In spite of rather small percentage of carbonates, an essential advantage of the Donbas Carboniferous succession is the presence of a great variety of marine and continental fossils, which provide reliable correlations not only to the regions of development of the marine rocks but also to continental subdivisions of Western Europe. The data obtained from the marine and continental fossils all prove that the Donets Basin Carboniferous is more complete than those in the other areas.

Conodonts are considered as the most reliable fossils for the definition of the stage boundaries and correlations. They occur in all types of marine rocks, widely distributed and are not as susceptible to provincialism as other groups. These features together with high rates of evolution ensure their successful use for Carboniferous biostratigraphy, and the Bashkirian-Moscovian boundary position in particular. For the purpose of regional and international correlation by conodonts, 6 most complete sections spanning the Bashkirian-Moscovian interval at the Donets Basin, Ukraine were selected in this study (Figs 1-2). The details of the conodont assemblages of 4 sections are updated in this paper (Figs 3-5; Tables 1-3). The potential markers and position of Bashkirian-Moscovian boundary are also discussed based on the conodont data presented herein.

\section{BASHKIRIAN-MOSCOVIAN BOUNDARY}

The boundary between the Global Bashkirian and Moscovian stages in their type areas and elsewhere was originally established by foraminifers. According to Unified 


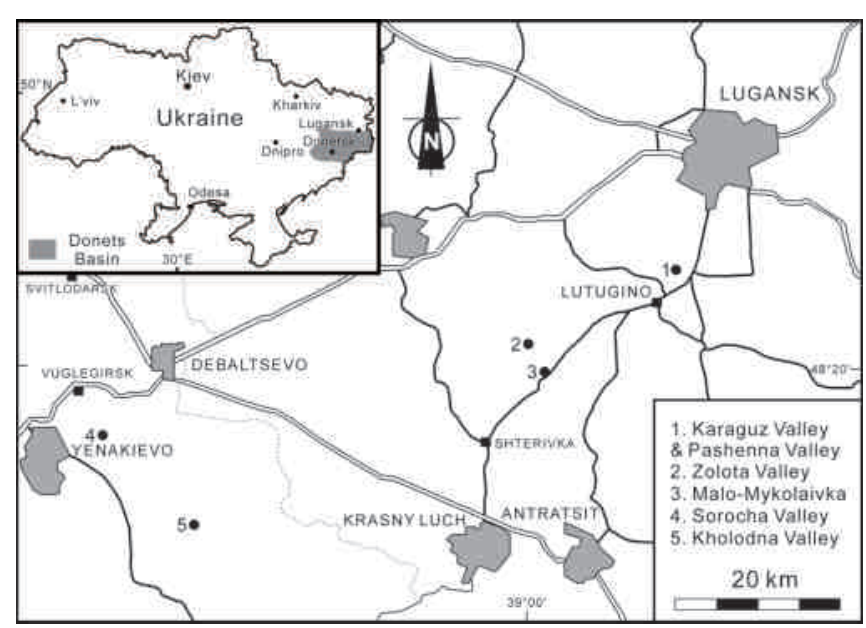

Figure 1. Locality map showing the studied sections.

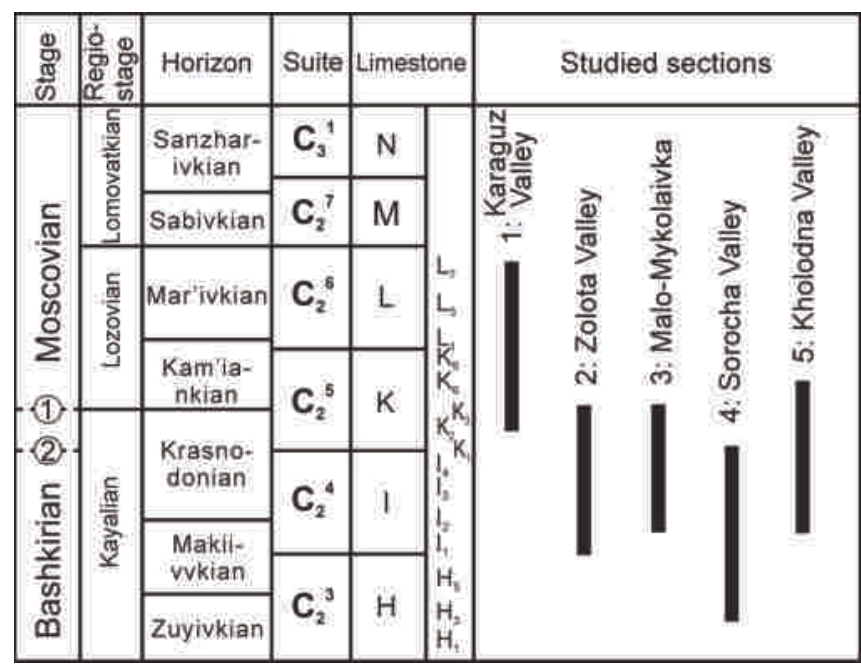

Figure 2. Stratigraphic range of studied sections. Encircled number 1 indicates traditional Bashkirian-Moscovian boundary level in Ukraine. Encircled number 2 shows the current Bashkirian-Moscovian boundary recognized by the FAD of Declinognathodus donetzianus.

Scheme of the East-European Platform 1988 (Resolutions, 1990), the lower boundary of the Moscovian Stage is defined by the foraminifer Aljutovella aljutovica (RauzerChernousova, 1938), whose first appearance datum (FAD) was found in the Aljutovo Formation at the base of the Vereian Substage in the Moscow Syneclise. The position of the Bashkirian-Moscovian boundary in the Donets Basin was defined mostly by correlation with foraminifers of the Moscow Syneclise and has not undergone radical changes for many years.

First, Kireeva (1951) included the whole $\mathrm{C}_{2}{ }^{5}(\mathrm{~K})$ Suite (formation) of the Donets Basin in the Moscovian Stage. Later, the lower boundary of the Moscovian was raised to limestone $\mathrm{K}_{3}$ within the same Suite (Aisenverg

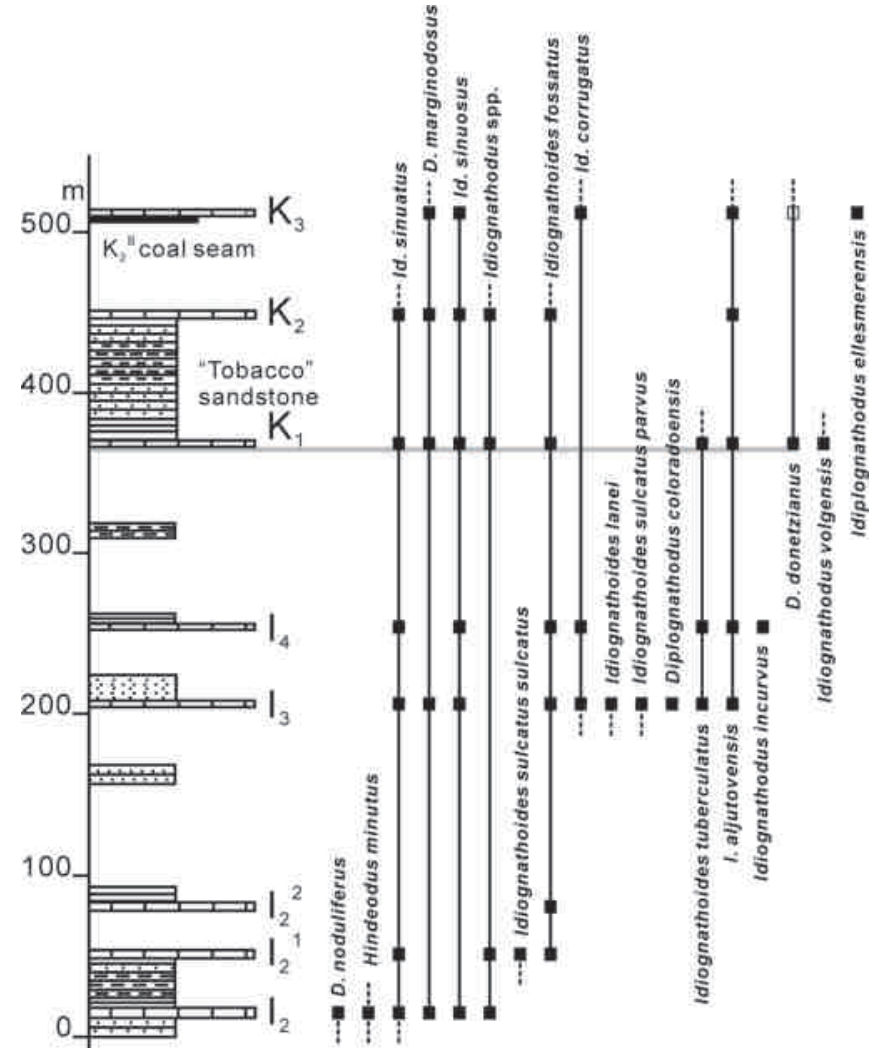

Figure 3. Range chart of important species across the BashkirianMoscovian boundary at the Malo-Mykolaivka section (updated from Nemyrovska et al., 2010, fig. 2).

et al., 1975). Nowadays it is reasonable to lower the Bashkirian/Moscovian boundary in the Donets Basin again down to the base of the $\mathrm{C}_{2}{ }^{5}(\mathrm{~K})$ Suite by the conodont correlation. Mostly because the conodont Declinognathodus donetzianus Nemirovskaya, 1990, which is considered to be a leading marker for the Bashkirian/Moscovian boundary, was found at the base of the Moscovian in its type area, and in the Donets Basin its FAD was recorded within the limestone $K_{1}$ at the base of the $C_{2}{ }^{5}(K)$ Suite or the base of the Lozovian Regional Stage of the Moscovian Stage (Nemyrovska, 2017). The exact position of the lower boundary of the Global Moscovian is still a subject of investigation by the International Task Group of the Carboniferous Subcommission.

The study of the Bashkirian-Moscovian boundary beds continues in the most complete sections around the world, including the Cantabrian Mountains, Spain; Urals, Russia; South China; and the Donets Basin, Ukraine. After the index species is officially selected, the investigations will be directed to establish the boundary stratotype. The Moscovian beds in the type area unconformably overlie the Mississippian carbonates. Only in the deep Aza Paleovalley they overlie comformably the uppermost Bashkirian continental and lagoonal sediments. Moreover, the basal Moscovian beds in the type area do not contain 


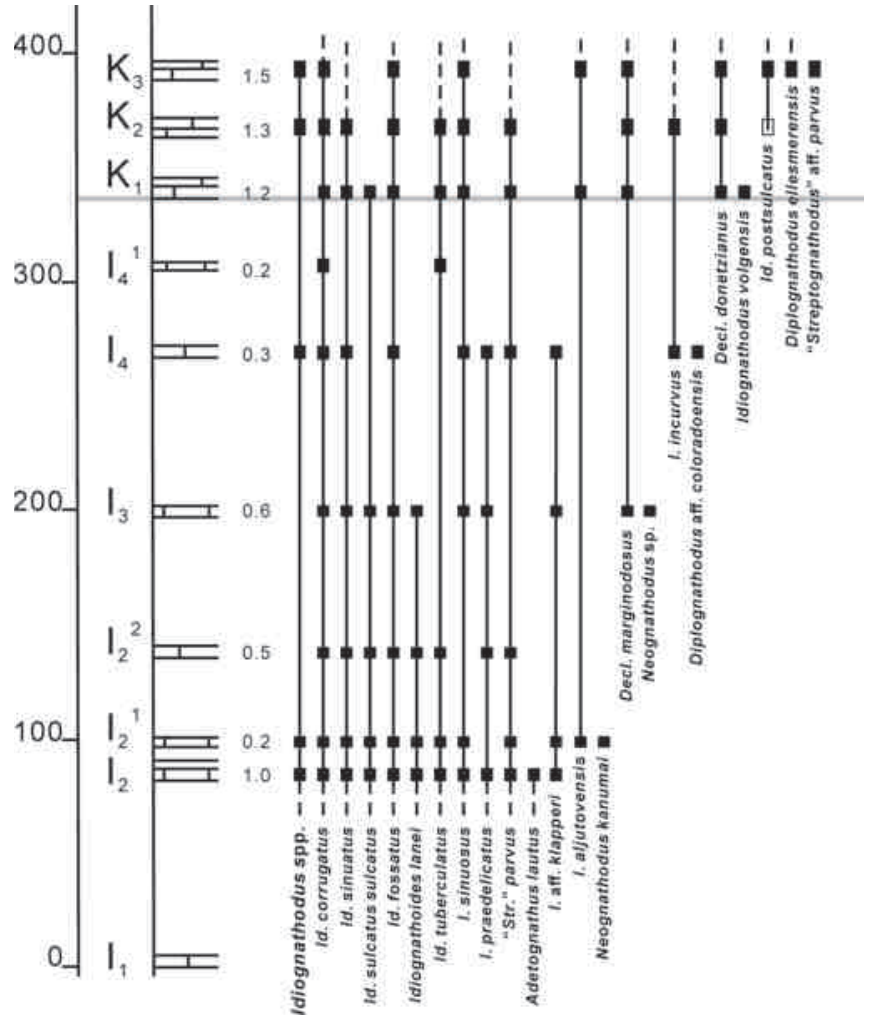

Figure 4. Range chart of important species across the BashkirianMoscovian boundary at the Zolota Valley Section (updated from Nemyrovska, 1999, fig. 21).

marine fossils. As a result, the stratotype of the BashkirianMoscovian boundary will be chosen in another region. The most perspective sections for establishing the GSSP at the lower boundary of the Moscovian nowadays are South Urals and South China. The Donets Basin will remain a key section of the Bashkirian-Moscovian boundary.

Since the Task Group to establish a GSSP close to existing Bashkirian-Moscovian boundary was organized, the members of the group were asked to submit the formal proposals for boundary-defining datums. Conodonts and fusulinid foraminifers were selected by the SCCS boundary Task Group as the main fossils for the definition of the boundary GSSP. It is known that the fusulinids are more provincial than the conodonts, which reduces their correlative potential.

The first proposals submitted by 2004 included the identifications of two independent conodont events and four events within fusulinoidean lineages.

The first conodont proposal submitted by Tamara I. Nemyrovska (Groves \& Task Group, 2003) considered two biotic events as potential boundary markers: 1) the evolutionary origin of Declinognathodus donetzianus from D. marginodosus (Grayson, 1984) (Fig. 6); and 2) evolutionary origin of Idiognathoides postsulcatus Nemyrovska, 1999 from Id. sulcatus sulcatus Higgins \&

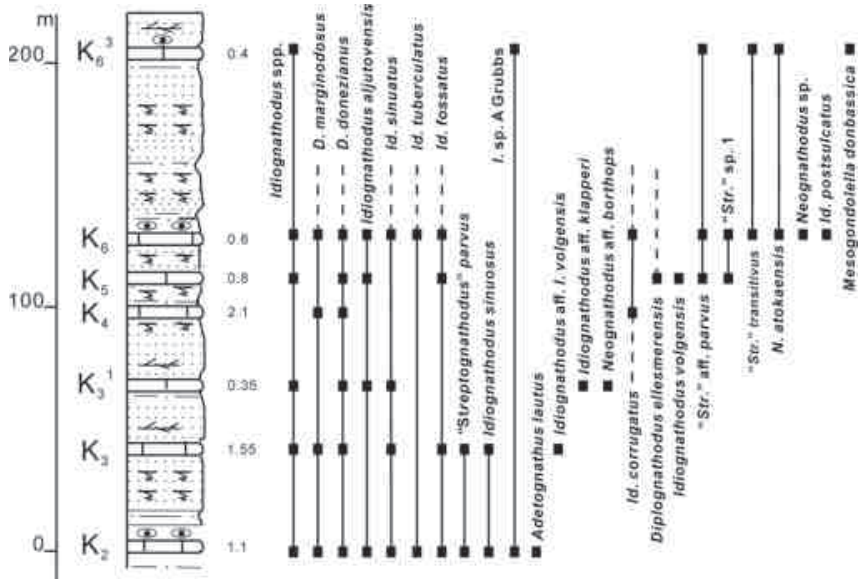

Figure 5. Range chart of important species across the BashkirianMoscovian boundary at the Karaguz Valley Section (updated from Nemyrovska, 1999, fig. 23).

Bouckaert, 1968. They were taxonomically characterized; their stratigraphic and geographic occurrences were well documented (Groves \& Task Group, 2004; Nemirovskaya, 1990; Nemyrovska, 1999, 2017).

Both phylogenetic lines are represented by the late species of the genera Declinognathodus and Idiognathoides. Both proposals were justified by the results of conodont investigations from the Bashkirian-Moscovian boundary beds of the Donets Basin and correlation to other regions. Declinognathodus donetzianus is easy to identify but is somewhat limited in its paleogeographic distribution. Idiognathoides postsulcatus is more widely distributed but is less easy to identify and maybe non-isochronic from region to region. Besides the Donets Basin, the lineage Declinognathodus marginodosus $-D$. donetzianus (or greater part of it) is known from the Bashkirian-Moscovian boundary transition of the Urals and Volga region of Russia (Kulagina et al., 2009; Sungatullina, 2014). Declinognathodus donetzianus was recorded at the base of the Moscovian Stage in its type area (Alekseev \& Goreva in Makhlina et al., 2001; Alekseev \& Goreva, 2013; Kabanov \& Alekseev, 2011). It was previously referred to other species from the Atokan of Alaska, North America (Savage \& Barkely, 1985, figs 10.1-10.4), the basal beds of the Bolsovian in Western Europe (van den Boogaard \& Bless, 1985, fig. 8.10) and Amazons Basin, South America (Lemos, 1992, pl. 3, fig. 1). One specimen of $D$. donetzianus has been recently found in the lower Atokan of the Appalachian Basin in the eastern U.S.A. (Work et al., 2012, fig. 8.1). In South China, only the lineage $I d$. sulcatus sulcatus - Id. postsulcatus was detected (Qi et al., 2016; Hu et al., 2017). In Spain, both lineages were reported but only a single non-illustrated specimen of $D$. donetzianus was reported (Blanco-Ferrera et al., 2009). 


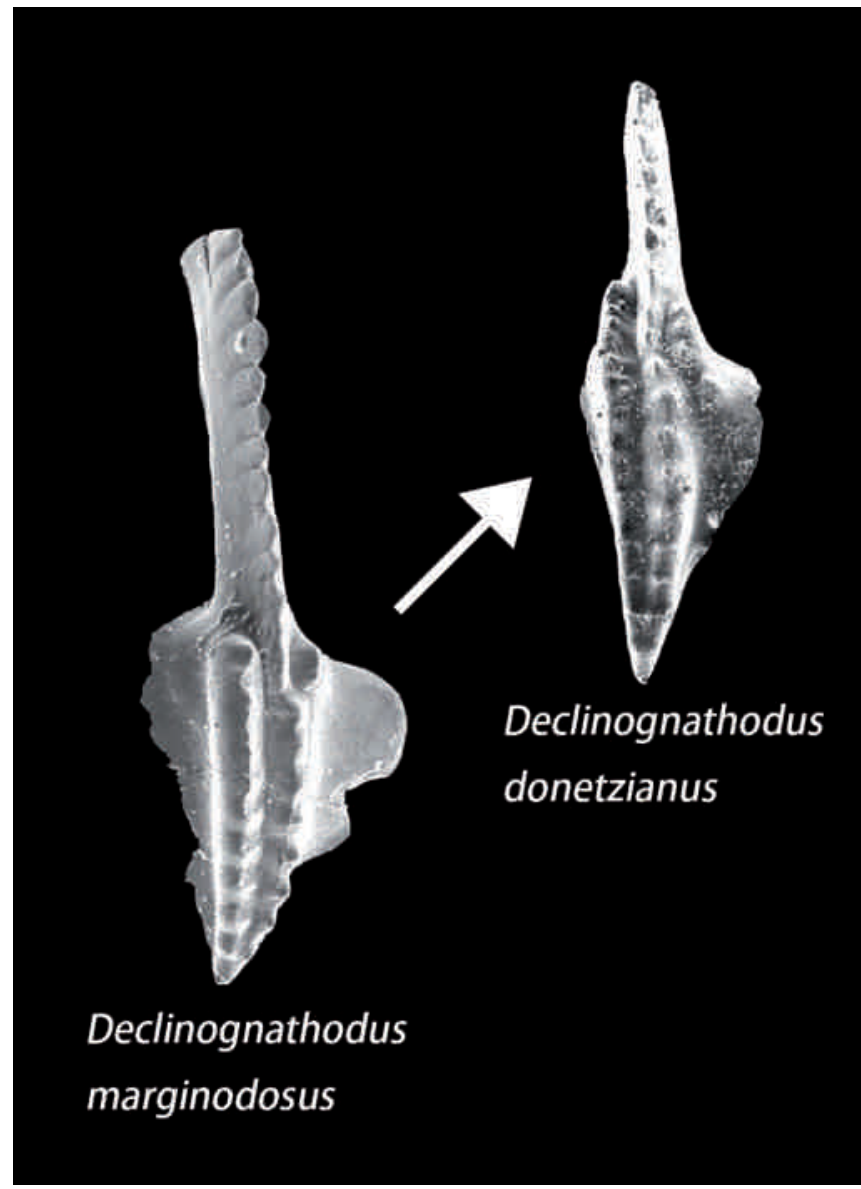

Figure 6. Evolutionary trend from Declinognathodus marginodosus to D. donetzianus in the BashkirianMoscovian transition (from Nemyrovska et al., 2010, fig. 3).

Later Lance L. Lambert proposed late morphotype of Neognathodus nataliae Alekseev \& Gerelzezeg in Makhlina et al., 2001 as boundary-defining potential marker (Groves and Task Group, 2006). The first occurrence of this species is known from the upper part of the Vereian Substage of the Moscow Syneclise, at the level much higher than the base of the Moscovian Stage in its type area (Goreva \& Alekseev in Makhlina et al., 2001). There is uncertainty with the taxonomic concept of late and early morphotypes. The species has also limited palaeogeographical distribution, it is known only in the Moscow Syneclise and North America so far. At this, $N$. nataliae was not properly documented yet in North America.

Another alternative-conodont Diplognathodus ellesmerensis Bender, 1980 was proposed as a marker for the definition of the Bashkirian-Moscovian boundary on the basis of detail investigation of one of the most complete carbonate succession in Asia, the Naqing section in South China (Qi et al., 2007). Abundant and diverse conodont association in this section contains different species of Diplognathodus, among them Di. ellesmerensis is common. This potential species-marker of the boundary was proposed in the hypothetical lineage $D i$. aff. orphanus Merrill, 1972 - Di. ellesmerensis (Wang \& Qi, 2003; Qi et al., 2013, 2016). Although Di. ellesmerensis is widespread, its relation to its potential ancestor $D i$. aff. orphanus is not clear yet.

Two other alternative conodont taxa, i.e., "Streptognathodus" expansus Igo \& Koike, 1964 and Mesogondolella, also have been proposed as markers for the definition of the Bashkirian-Moscovian boundary (Qi et al., 2007). However, the different ranges (FAD in particular), uncertain origination and stratigraphic distance from the traditional lower Moscovian boundary limit their utility to be as boundary markers.

Recently, Goreva and Alekseev proposed to move the lower boundary of the Moscovian one substage higher, from the base of the Vereian (lowermost Moscovian) to the base of the Kashirian (Alekseev \& Goreva, 2013), by using the FAD of Neognathodus bothrops Merrill, 1972, which probably derived from $N$. atokaensis Grayson, 1984. Neognathodus bothrops is known from North America, Moscow Basin, Urals, Ukraine (rare) and several specimens in South China. In the Donets Basin, two specimens of $N$. aff. $N$. bothrops were found in the lower Moscovian beds of the Karaguz and Pashenna Valley sections. Real $N$. bothrops was not found. The entry of $N$. atokaensis was recorded at the base of the second Moscovian conodont zone, limestone $\mathrm{K}_{6}$ (Table 3 ). If $N$. bothrops would be accepted as a boundary marker the movement of the lower Moscovian boundary will require the redefinition of the scopes of the Bashkirian and Moscovian stages. The proposal had negligible support (Groves \& Task Group, 2006).

Among the foraminifers, the representatives of Profusulinella were selected as potential markers of the Bashkirian/Moscovian boundary. The proposed fusulinoidean lineages include 1) evolutionary changes within the Profusulinella phylogeny; 2) the evolutionary appearance of Aljutovella (from Profusulinella); 3) the evolutionary appearance of Neostaffella (from Pseudostaffella); and 4) the evolutionary appearance of Eofusulina (from Verella) (Groves \& Task Group, 2003). Kulagina (2009) proposed to use FAD of Depratina prisca (Deprat, 1912) within the lineage Srafflaeformes - Depratina to define the base of the Moscovian. The alternative species could be Aljutovella aljutovica (RauzerChernousova, 1938) and Skelnevatella skelnevatica (Putrya \& Leontovich, 1948) (Kulagina, 2009). Except conodont Declinognathodus donetzianus and Diplognathodus ellesmerensis, none of other proposed events possesses optimal global correlation so far due to their relatively restricted geographic distribution (Alekseev \& Task Group, 2013). 


\section{REGIONAL STRATIGRAPHY OF THE BASHKIRIAN-MOSCOVIAN BOUNDARY BEDS}

The studied stratigraphic interval includes the Krasnodonian Horizon of the Kayalian Regiostage of the Bashkirian Stage (the $\mathrm{C}_{2}{ }^{4}$ (I) Suite = formation) and the Kamiankian Horizon of the Lozovian Regiostage of the lower Moscovian (the $\mathrm{C}_{2}^{5}$ (K) Suite) (Fig. 2).

The Krasnodonian Horizon is represented by predominantly marine rocks with thin coal seams. Darkgrey mudstones, packstones and wackestones within the terrigenous strata contain foraminifers, conodonts, brachiopods, algae, pelecypods and rare ammonoids of the Diaboloceras-Axinolobus Genozone (Popov, 1979). Grainstones with diverse detrital material and algal limestones occur in places.

The Kamiankian Horizon consists of thick, grainy sandstones alternating with marshes deposits that contain numerous limestone interlayers and coal seams. In general, shallow marine and lagoon deposits dominate in the lower part of the $\mathrm{C}_{2}{ }^{5}(\mathrm{~K})$ Suite. The limestones are grey and darkgrey platy wackestones and packstones; algal in places. Conodonts, foraminifers, brachiopods, crinoids, ostracods, some corals and other marine fossils are characteristic of this lower part of the $\mathrm{C}_{2}{ }^{5}$ Suite. The greater number of conodonts occurs in the upper parts of the limestone beds, especially in limestones $\mathrm{K}_{1}$ and $\mathrm{K}_{3}$. A coal seam occurs at the base of limestone $\mathrm{K}_{3}$ (Fig. 7a).

Ammonoids of the Diaboloceras - Axinolobus Genozone were found in the lower part of the $\mathrm{C}_{2}{ }^{5}(\mathrm{~K})$ Suite (Popov, 1979). Above limestone $K_{1}$ that contains abundant Donezella algae in places, thick graywacke sandstone with an

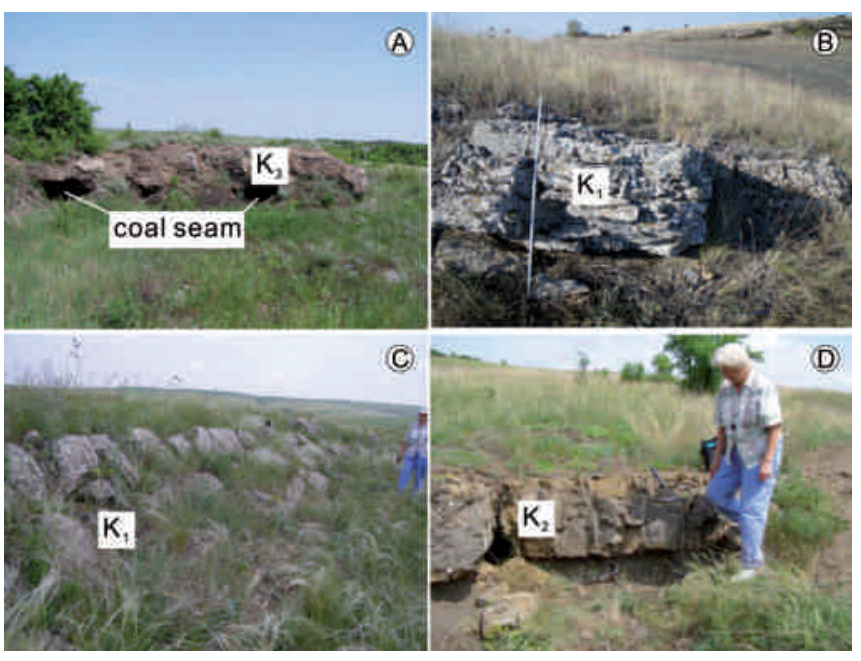

Figure 7. a) $\mathrm{K}_{3}$ limestone and coal seam of the Malo-Mykolaivka section. b) $\mathrm{K}_{1}$ limestone of the Malo-Mykolaivka section. c) $\mathrm{K}_{1}$ limestone of the Zolota Valley section. d) $\mathrm{K}_{2}$ limestone of the Zolota Valley section. admixture of effusive volcanic material, so-called tobaccosandstone, occurs. Fissunenko (1991) found numerous remains of a Duckmantian flora (Westphalian B). In the middle part of the formation, Fissunenko (1991) found a Bolsovian flora (Westphalian C) and ammonoids of the Diaboloceras - Winslowoceras Genozone (Popov, 1979).

Conodonts in the lower half of the $\mathrm{C}_{2}{ }^{5}(\mathrm{~K})$ Suite are identical to the Vereian conodonts of the Moscow Syneclise, basal part of the Bolsovian or Westphalian C of Europe, lower Dalaun of China and Atokan of North America. The upper part of the suite is characterized by the wide distribution of alluvial sandstones, thick limestones, microbial limestones in places, and a great number of coal seams.

\subsection{The sections}

The most complete sections, which contain the stratigraphically important conodonts are as follows (Figs 1-2): 1) The Zolota Valley (N48 $21.5^{\prime}, \mathrm{E}^{\circ} 9^{\circ} 00.0^{\prime}$ ), left bank of the Olkhova River, not far from the southeastern side of Yelisavetovka Village, $2.5 \mathrm{~km}$ south of Illiria Village, Lugansk County; 2) The Karaguz Valley and Pashenna Valley (N48 $\left.26.2^{\prime}, \mathrm{E}^{\circ} 9^{\circ} 14.3^{\prime}\right), 1.5 \mathrm{~km}$ from each other, left bank of the Olkhova River. North-northeastern side of Lutugino, Lugansk County; 3) The Malo-Mykolaivka section (N48 $\left.18.9^{\prime}, \mathrm{E} 39^{\circ} 01.1^{\prime}\right)$, northern side of MaloMykolaivka Village, along the Lugansk-Krasny Luch road, Lugansk County; 4) The Sorocha Valley (N48 $15.2^{\prime}$, E3 $\left.8^{\circ} 18.7^{\prime}\right)$, left side of the Bulavin River, northeastern side of Bulavinske Village, Yenakievo District, Donetsk County; and, 5) The Kholodna Valley (N48 09'32", E38 $\left.28^{\prime} 18^{\prime \prime}\right)$, left tributary of Kharcyzsk stream, close to the northern side of Kirovskoje, Shakhtersk District, Donetsk County.

Two additional sections spanning the BashkirianMoscovian transition are in the process of investigation. In this paper, attention is paid to three sections, which are considered to be the most complete in the Donets Basin. They contain the most representative fauna (at least conodonts and foraminifers) of the Bashkirian-Moscovian boundary interval. These are the Zolota Valley (Fig. 4) and the Malo-Mykolaivka sections (Fig. 3) where all the limestones of the $\mathrm{C}_{2}{ }^{4}$ (I) Suite and the lower limestones $\left(\mathrm{K}_{1}, \mathrm{~K}_{2}\right.$ and $\left.\mathrm{K}_{3}\right)$ of the $\mathrm{C}_{2}{ }^{5}(\mathrm{~K})$ Suite are well exposed. We use the data of the lower half of the Karaguz and Pashenna sections (Fig. 6), up to limestone $\mathrm{K}_{6}^{3}$, where new conodont species appeared, including "Streptogathodus" transitivus Kossenko in Kozitskaya et al., 1978, the name-bearer of the younger, second zone of the Moscovian Stage.

The short descriptions of the limestones of the MaloMykolaivka, Zolota Valley, Karaguz and Pashenna sections is given below. The Malo-Mykolaivka and Zolota Valley sections are located close and will be described together. 


\subsubsection{Malo-Mykolaivka and Zolota Valley sections} (Figs 3-4; Tables 1-2)

The distance between limestones of the Malo-Mykolaivka section was measured by Prof. K. Ueno (Ueno \& Nemyrovska, 2008).

The limestone $\mathrm{I}_{1}$ is float shales, dark grey wackestone, yellowish-brownish mineralized in places. Conodonts were not found.

The lowest limestone of the studied interval, yielding the conodonts, in the Zolota Valley and Malo-Mykolaivka sections is limestone $\mathrm{I}_{2}$.

Limestone $\mathrm{I}_{2}, 4 \mathrm{~m}$ thick in the Malo-Mykolaivka and $1 \mathrm{~m}$ thick in the Zolota Valley sections. It is darkgrey, bioclastic wackestone in the uppermost part of the member and grainstone at the base. The conodont sample was taken from the top of the limestone in the Malo-Mykolaivka section. The conodont association is dominated by Declinognathodus noduliferus. The FAD of D. marginodosus is registered in this limestone. This species is represented here by small number of specimens. In the Zolota Valley, the conodont samples were taken in the middle and close to the base of limestone. Declinognathodus marginodosus was not found. Idiognathoides sinuatus Harris \& Hollingsworth, 1933 dominate. Several specimens of Idiognathodus were also found. Algae and brachiopods occurred in the uppermost part of the limestone. Brachiopods occur also in the middle part of the limestone.
Limestone $\mathrm{I}_{2}{ }^{1}, 1.0 \mathrm{~m}$ thick in the Malo-Mykolaivka section and $0.2 \mathrm{~m}$ thick in the Zolota Valley section. In the Malo-Mykolaivka section, it occurs $40 \mathrm{~m}$ above the limestone $\mathrm{I}_{2}$. It is dark-grey packstone with algae and grainstone with silty and muddy interbeds, grainy at the bottom. In the Zolota Valley, it contains a numerous conodont association dominated by diverse species of Idiognathoides. Idiognathodus species are also common. Fragments of brachiopods occur.

Limestone $\mathrm{I}_{2}^{2}, 0.5 \mathrm{~m}$ thick in the Malo-Mykolaivka and Zolota Valley sections. In Malo-Mykolaivka section, it occurs $30 \mathrm{~m}$ above the limestone $\mathrm{I}_{2}{ }^{1}$. It is dark-grey bioclastic partly algal, partly crinoidal limestone with Zoophycus at the top. Brachiopods and corals occur. This limestone in the Zolota Valley section contains a numerous and diverse conodont association of idiognathoidids. Only several specimens of $I d$. sinuatus together with fish remains and ostracods were received from a small sample of limestone $\mathrm{I}_{2}^{2}$ of the Malo-Mykolaivka section.

Limestone $\mathrm{I}_{3}, 0.55 \mathrm{~m}$ thick, mostly chucks in the Malo-Mykolaivka section, and $0.3 \mathrm{~m}$ thick in the Zolota Valley section. In Malo-Mykolaivka section it occurs $85 \mathrm{~m}$ above the limestone $\mathrm{I}_{2}^{2}$. It is dark-grey bioclastic packstone and thinly bedded grainstone with conodont association, consisting mostly of Idiognathoides species. Declinognathodus marginodosus is common. Idiognathodus species also occur.

Table 1. Numerical chart of the conodonts from the Malo-Mykolaivka section (updated from Nemyrovska, 1999).

\begin{tabular}{|c|c|c|c|c|c|c|c|c|c|c|c|c|c|}
\hline \multirow{2}{*}{$\begin{array}{l}\text { Stage } \\
\text { Limestone }\end{array}$} & \multicolumn{6}{|c|}{ Bashkirian } & \multicolumn{7}{|c|}{ Moscovian } \\
\hline & $\mathrm{I}_{2}$ & $1_{2}^{\prime}$ & $\mathrm{I}_{2}{ }^{2}$ & $\mathrm{I}_{3}$ & $\mathrm{I}_{4}$ & $\mathrm{~K}_{1}$ basc & $\mathrm{K}_{1}$ & $\mathrm{~K}_{1}$ top & $\mathrm{K}_{2}$ grey & $\mathrm{K}_{2}$ & $\mathrm{~K}_{3}$ basc & $\mathrm{K}_{3}$ & $\mathrm{~K}_{3}$ top \\
\hline Declimognathodus noduliferus & 50 & & & & & & & & & & & & \\
\hline Declinognathodus marginodosus & 7 & & & 9 & & 9 & & 34 & 5 & 17 & 58 & 20 & 5 \\
\hline D. marginodosus $-D$. donetziamus & & & & & & & & & & & & 1 & \\
\hline Declinognathodus donetzianus & & & & & & & & 2 & & & & & 1? \\
\hline Idiognathoides sinuatus & 6 & 10 & & 47 & 18 & 3 & 6 & 46 & & 6 & & & \\
\hline Idiognathoides corrugatus & & & & 4 & 5 & & & & & & 2 & & \\
\hline Hindeodus minutus & 4 & & & & & & & & & & & & \\
\hline Idiognathoides fossatus & & 16 & 4 & 50 & 156 & & 29 & 140 & & 21 & & & \\
\hline Idiognathoides sulcatus sulcatus & & 3 & & & & & & & & & & & \\
\hline Idiognathoides sulcatus parvus & & & & 9 & & & & & & & & & \\
\hline Id. simuatus - Id. tuberculatus & & 2 & & & & & & & & & & & \\
\hline Idiognathoides tuberculatus & & & & 2 & 60 & & & 31 & & & & & \\
\hline Idiognathoides lanei & & & & 5 & & & & & & & & & \\
\hline Idiognathodus simuosus & 8 & & & 7 & 5 & 11 & 7 & 16 & & 36 & 2 & & \\
\hline Idiognathodus volgensis & & & & & & & 5 & 65 & & & & & \\
\hline Idiognathodus aljutovensis & & & & 1 & 21 & & 6 & 70 & & 10 & 3 & & \\
\hline Idiognathodus incurvus & & & & & 3 & & & & & & & & \\
\hline Diplognathodus ellesmerensis & & & & & & & & & & & & 1 & \\
\hline Diplognathodus coloradoensis & & & & 1 & & & & & & & & & \\
\hline Idiognathodus spp. & 1 & 9 & & & & & 4 & & & 5 & & & \\
\hline Total weight of the sample $(\mathrm{kg})$ & 10 & 10 & 3 & 10 & 12 & 6 & 10 & 14 & 8 & 12 & 12 & 12 & 12 \\
\hline
\end{tabular}


Table 2. Numerical chart of the conodonts from the Zolota Valley section (updated from Nemyrovska, 1999, fig. 22).

\begin{tabular}{|c|c|c|c|c|c|c|c|c|c|c|}
\hline Stage & & & Bash & $\tan$ & & & & Mosco & rian & \\
\hline Limestone & $\mathrm{T}_{2}$ & $\mathrm{I}_{2}{ }^{1}$ & $\mathrm{I}_{2}^{2}$ & $\mathrm{I}_{3}$ & $\mathrm{I}_{4}$ & $\mathrm{I}_{4}^{\prime}$ & $\mathrm{K}_{1}$ & $\mathrm{~K}_{1}$ top & $\mathrm{K}_{2}$ & $\mathrm{~K}_{3}$ \\
\hline Declinognathodus marginodosus & & & & 3 & & & 15 & 18 & 10 & 70 \\
\hline Declinognathodus donetziamus & & & & & & & & 1 & 7 & 8 \\
\hline ldiognathoides sulcatus sulcatus & 4 & 1 & 4 & 2 & & & 1 & & & \\
\hline ldiognathoides sinuatus & 48 & 45 & 112 & 22 & 37 & 4 & 13 & $>200$ & 12 & \\
\hline Idiognathoides corrugatus & 36 & 32 & 55 & 11 & 19 & 2 & 4 & 4 & 5 & 1 \\
\hline Idiognathoides fossatus & 7 & 19 & 49 & 22 & 34 & & 21 & $>200$ & 9 & 20 \\
\hline Idiognathoides postsulcatus & & & & & & & & & 2 ? & 2 \\
\hline Idiognathoides tuberculatus & 3 & 1 & 2 & & & 3 & 1 & 170 & 8 & \\
\hline Idiognathoides lanei & 10 & 10 & 2 & 3 & & & & & & \\
\hline Adeiognathus lautus & 1 & & & & & & & & & \\
\hline "Streplognathodus " parvus & 2 & 3 & 2 & & 1 & & 2 & & 1 & \\
\hline "Streptognathodus" aff. "S." parvus & & & & & & & & & & 2 \\
\hline Idiognathodus aljutovensis & & 12 & & & & & & I & & 1 \\
\hline Idiognathodus incurvus & & & & & 4 & & & & 2 & \\
\hline Tdiognathodus simoosus & 3 & 5 & & 6 & 18 & & 20 & 15 & 3 & 5 \\
\hline Idiognathodus volgensis & & & & & & & & 1 & & \\
\hline Idiognathodus praedelicatus & 3 & & 1 & 2 & 8 & & & & & \\
\hline Idiognathodus aff, I. klapperi & 7 & 11 & & 1 & 2 & & & & & \\
\hline Tdiognathodus spp. & 6 & & & & 20 & & & & 14 & 5 \\
\hline Neognathodus kamumai & & 1 & & & & & & & & \\
\hline Neognathodus sp. & & & & 1 & & & & & & \\
\hline Diplognathodus coloradoensis & & & & & 1 & & & & & \\
\hline Diplognathodus ellesmerensis & & & & & & & & & & 1 \\
\hline Total weight of the sample $(\mathrm{kg})$ & 9 & 9 & 9 & 9 & 11 & 4 & 12 & 10 & 15 & 12 \\
\hline
\end{tabular}

Limestone $\mathrm{I}_{4}, 0.4 \mathrm{~m}$ thick in the Malo-Mykolaivka section and $0.3 \mathrm{~m}$ thick in the Zolota Valley section. In the MaloMykolaivka section, it occurs $45 \mathrm{~m}$ above the limestone $\mathrm{I}_{3}$. It is dark-grey bioclastic packstone and grainstone with silty layers, with thin beds in places. Idiognathoides species dominate but the species of Idiognathodus also common in both sections. Algae, ostracods, foraminifers, fish remains and coral fragments occur.

Limestone $\mathrm{I}_{4}{ }^{1}, 0.2 \mathrm{~m}$ thick in the Zolota Valley sections. In the Malo-Mykolaivka section, this limestone was not found. In the Zolota Valley, this limestone is brownish-grey packstone, bedded, silty, with small number of conodonts of Idiognathoides and corals.

Limestone $\mathrm{K}_{1}, 0.9 \mathrm{~m}$ thick in the Malo-Mykolaivka section (Fig. 7B) and $1.2 \mathrm{~m}$ thick in the Zolota Valley section (Fig. 7C). Grey and dark grey bioclastic packstone, fine grained grey peloidal wackestone, crinoidal at the top, in the middle part lense-like algae interlayer occurs, the base with crinoids, rare brachiopods and ostracods. Rich conodont association contains abundant conodonts of the Idiognathoides genus and rather numerous species of Idiognathodus. The top of limestone $\mathrm{K}_{1}$ is much more productive for conodonts than the middle part or the base. The same conodont association is characteristic of the top of limestone $\mathrm{K}_{1}$ in the Zolota Valley section. Here the FAD of Declinognathodus donetzianus was established by only single specimens of $D$. donetzianus in both sections.
Limestone $\mathrm{K}_{2}, 0.7 \mathrm{~m}$ thick in the Zolota Valley section and $0.6 \mathrm{~m}$ thick in the Malo-Mykolaivka section (Fig. 7D). In the Malo-Mykolaivka section, the limestone occurs 85 $\mathrm{m}$ above the limestone $\mathrm{K}_{1}$. Between these limestones a thick green-brownish sandstone (Fig. 8), which is so-called

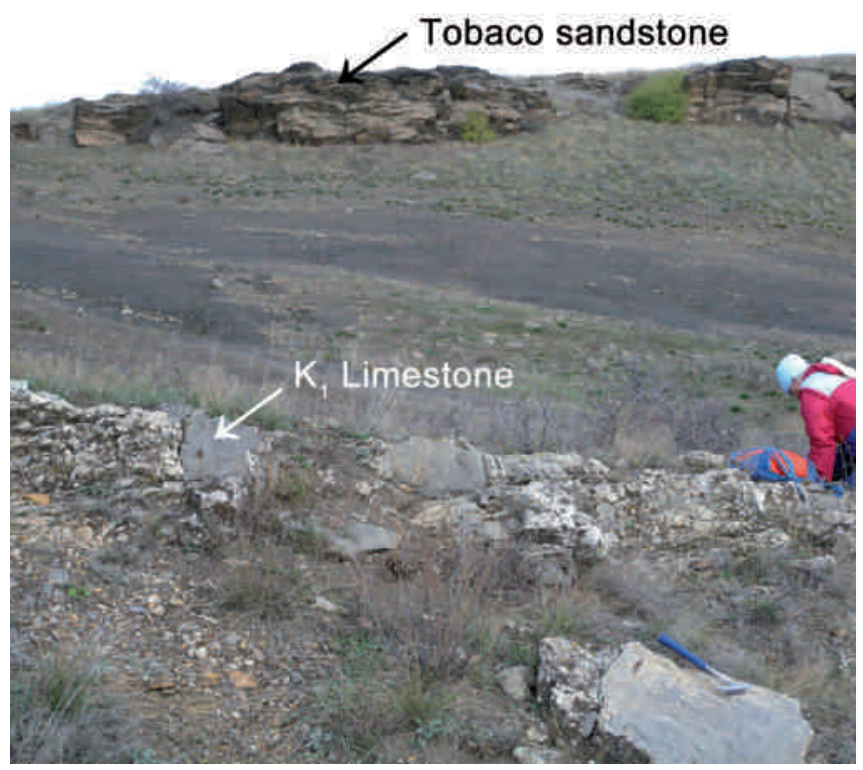

Figure 8. $\mathrm{K}_{1}$ limestone and "tobacco sandstone" of the MaloMykolaivka section, marine shales between them. Estwing hammer for scale $=33 \mathrm{~cm}$ length. 
"tobacco sandstone" due to its colour, with flora occurs. In the Zolota Valley section, $\mathrm{K}_{2}$ is grey wackestone/packstone with Idiognathoides and Declinognathodus species. Seven specimens of $D$. donetzianus were identified. In the Malo-Mykolaivka section, it is mostly grainstone and packstone. The upper part is dolomitized, middle part with Donezella, dolomitic layer at the bottom. The conodonts are not numerous. Idiognathoides species dominate. Algae, bryozoans and crinoids occur.

Limestone $\mathrm{K}_{3}, 1.3 \mathrm{~m}$ thick in the Malo-Mykolaivka section (Fig. 7A). This dark nodular limestone occurs $60 \mathrm{~m}$ above the $\mathrm{K}_{2}$ limestone. It is sandy at the base. In the MaloMykolaivka section, $15 \mathrm{~cm}$ above the base it is a dark grey wackestone with $D$. marginodosus (58 specimens), higher thinly bedded grey and dark grey wackestone/packstone occur. Below the base of this limestone in both sections a coal seam occurs. In both sections $D$. marginodosus dominate. Idiognathoides species play subordinate role. In the Zolota Valley, 8 D. donetzianus were found. Crinoids and ostracods occur.

\subsubsection{Karaguz (KA) and Pashenna (PA) sections (Fig. 5; Table 3)}

Limestone $\mathrm{K}_{2}$ (KA), $0.65 \mathrm{~m}$ to $1.1 \mathrm{~m}$ thick. It is bioclastic grainstone/packstone found mostly in chunks. Idiognathoides species dominate. Declinognathodus donetzianus and D. marginodosus are common. Few Idiognathodus species occur.

Limestone $\mathrm{K}_{3}$ (KA), $1.5 \mathrm{~m}$ thick bioclastic grainstone with some algae in places, Idiognathoides species and Idiognathodus sinuosus Ellison \& Graves, 1941 are common. Declinognathodus donetzianus is rare. Declinognathodus marginodosus dominates in Limestone $\mathrm{K}_{3}$ of the Pashenna section. In the Karaguz section it contains foraminifers Eofusulina triangula (RauzerChernousova \& Beljaev in Rauzer-Chernousova et al., 1936), brachiopods, crinoids, ostracods, gastropods and others. These fossils are common in the Pashenna $\mathrm{K}_{3}$ Limestone.

Limestone $\mathrm{K}_{3}{ }^{1}$ (PA), $0.35 \mathrm{~m}$ thick. It is grey to dark grey bioclastic limestone with conodonts mostly Declinognathodus marginodosus, few D. donetzianus and foraminifers (Ozawainella abundant, Eofusulina triangula common).

Limestone $\mathrm{K}_{4}(\mathrm{PA})$, float $2.1 \mathrm{~m}$ thick. Bioclastic limestone. Mostly crinoidal and fusulinid grainstone. Conodonts are not numerous, Declinognathodus marginodosus is common, few D. donetzianus and Idiognathoides corrugatus (Harris \& Hollingsworth, 1933) occur. Brachiopods (Choristites) occur.

Limestone $\mathrm{K}_{5}(\mathrm{PA})$, float $0.8 \mathrm{~m}$ thick. Grey wackestone, partly dolomitized, partly with fine sand-carbonate muddy interlayers. Conodont association contains Declinognathodus donetzianus and Idiognathodus species.
Table 3. Numerical chart of the conodonts from the Pashenna Valley and Karaguz Valley sections (updated from Nemyrovska, 1999, figs 24, 25).

\begin{tabular}{|c|c|c|c|c|c|c|c|c|}
\hline \multirow{3}{*}{$\begin{array}{l}\text { Stage } \\
\text { I.imestone }\end{array}$} & \multicolumn{2}{|c|}{ Karaguz } & \multicolumn{6}{|c|}{ Pashennayu Vulley } \\
\hline & \multicolumn{2}{|c|}{ Moscovian } & \multicolumn{6}{|c|}{ Moscovian } \\
\hline & $\mathrm{K}_{2}$ & $\mathbf{K}_{5}$ & $\mathrm{~K}_{3}$ & $\mathrm{~K}_{1}{ }^{1}$ & $K_{1}$ & $\mathrm{~K}_{\mathrm{s}}$ & $K_{\mathrm{n}}$ & $\mathbf{K}_{a}^{3}$ \\
\hline Declinognathodus marginodosus & 19 & 1 & 18 & & 11 & 1 & 95 & \\
\hline Declinognathodas donetzismus & 27 & 2 & & 8 & 2 & 5 & 12 & \\
\hline Idiogrusthoides simnatus & 18 & 11 & & 4 & & & 30 & \\
\hline Idiognathoides commgutus. & & & & & 5 & & 34 & \\
\hline Idiogrnuhoides fossutus & 97 & 12 & & & & 4 & 45 & \\
\hline Fdiognathoules postsulcertus & & & & & & & 5 & \\
\hline fliogrtathoides fubercoklatis' & 71 & & & & & & 32 & \\
\hline Iliognathodus simuosus & 78 & 16 & & & & & & \\
\hline Idiognuthodus aljutovensis & 6 & & & 3 & & 2 & 1 & \\
\hline fdiognathodus aff. I. klapperi & & & & 3 & & & & \\
\hline Idiogyzuthodus sp. A Grubbs & 2 & & & & & & & 1 \\
\hline Jiognathodus spp. & 8 & 3 & 5 & 15 & & II & 2 & 50 \\
\hline "Streptognathodiss" parvus & 15 & 7 & & & & & & \\
\hline "Streptognathodus" aff. "S." parvis & & & & & & 3 & 4 & 85 \\
\hline "Streptognathodus" transitivus & & & & & & & 4 & 18 \\
\hline "Streptognathodus" sp. I & & & & & & 4 & 5 & \\
\hline Neognathodus aff. $N$, bothrops & & & & 2 & & & & \\
\hline Idiognathodus volgensis & & & & & & 1 & & \\
\hline fdiognathodus aff $t$, volgensis & & 1 & & & & & & \\
\hline Neognathodus aff. $N$. candatus & & & & & & & 2 & \\
\hline Neognathodus atokaensis & & & & & & & 1 & 3 \\
\hline Neognthodns sp. & & & & & & & 1 & \\
\hline Adetognatlins lautus & 3 & & & & & & & \\
\hline Diplognothodus ellesmerensis & & & & & & 1 & & \\
\hline Merogondolella domhassica & & & & & & & & 15 \\
\hline Total weight of the sample $(\mathrm{kg})$ & 1.3 & 10 & 8 & 6 & 16) & 6 & 10) & 10) \\
\hline
\end{tabular}

The FOD of Diplognathodus ellesmerensis (1 specimen) is registered. Fusulinids are abundant, and ostracods are common.

Limestone $\mathrm{K}_{6}$ (PA), float, $0.4 \mathrm{~m}$ thick. Bioclastic limestone, mostly platy, thinly bedded wackestone, some interlayers of packstone occur. Declinognathodus marginodosus and Idiognathoides sinuatus and Id. fossatus (Branson \& Mehl, 1941) dominate. The FOD of "Streptognathodus" transitivus is recorded at this level.

Limestone $\mathrm{K}_{6}{ }^{3}$ (PA), float, the chunks of bioclastic limestone, grey and yellow-brownish, sandy in places, rarely muddy in places. Abundant conodonts, "Streptognathodus" aff. "S." parvus dominates. FODs of Neognathodus atokaensis and Mesogondolella donbassica (Kossenko, 1975) are recorded at this level.

The numerical distribution of conodonts in the studied sections show that the most common conodonts are Idiognathoides sinuatus and Id. corrugatus. Idiognathoides fossatus and Id. tuberculatus join them in the upper Bashkirian in the upper part of the $\mathrm{C}_{2}{ }^{4}$ (I) Suite. An insignificant quantity of Id. sulcatus and Id. sulcatus parvus are also recorded at that level. Several specimens of Id. postsulcatus were found in limestones $\mathrm{K}_{2}-\mathrm{K}_{6}$ of the $\mathrm{C}_{2}{ }^{5}$ (K) suite of the lower Moscovian. Numerous conodonts of Declinognathodus are found in all limestones of the upper part of the Bashkirian through the lower half of the $\mathrm{C}_{2}{ }^{5}(\mathrm{~K})$ Suite of the Moscovian. The lineage $D$. noduliferus $-D$. marginodosus $-D$. donetzianus is traced from the basal limestones of the $\mathrm{C}_{2}{ }^{4}$ (I) Suite through the middle of the $\mathrm{C}_{2}{ }^{5}(\mathrm{~K})$ Suite (limestones $\mathrm{I}_{2}-\mathrm{K}_{7}$ ). 
Declinognathodus donetzianus was found in the Zolota Valley and Malo-Mykolaivka sections in the uppermost part of limestone $\mathrm{K}_{1}$ of the $\mathrm{C}_{2}{ }^{5}(\mathrm{~K})$ Suite, which in the Ukrainian Regional Stratigraphic Scheme still belongs to the uppermost Kayalian Regiostage of the uppermost Bashkirian (Fig. 2) (Poletaev et al., 2013). Although only a single specimen of $D$. donetzianus was found in limestone $\mathrm{K}_{1}$, it had fully developed features of the species (Fig. 6). As the lineage $D$. marginodosus $-D$. donetzianus can be traced in other regions as well, although not as distinct as in the Donets Basin, the FAD of D. donetzianus can serve as a most reliable level for recognition of the BashkirianMoscovian boundary. In fact, it is reasonable as $D$. donetzianus occur at the base of the Moscovian Stage in its type area. The distribution pattern of conodonts in the Zolota Valley is very close to that of the Malo-Mykolaivka section and of the Kholodna Valley as well (Figs 3-5).

\subsection{The conodonts}

Most sections were first measured and sampled for conodonts in the 1970s and 1980s. Later in 1990s, when the Carboniferous Subcommission started to work on the refinement of the Carboniferous stage boundaries, they were re-studied along with additional new good sections spanning the Bashkirian-Moscovian transition. The detail studies of some of them are still in progress.

One of such new sections is the Malo-Mykolaivka section found about twelve years ago by advice of famous late Ukrainian Carboniferous paleobotanist Prof. O. Fissunenko (Lugansk State University, Donets Basin). It contains probably the most complete conodont and fusulinid succession of the Bashkirian-Moscovian transition in the Donets Basin (Ueno \& Nemyrovska, 2008; Nemyrovska et al., 2010).

The samples from all sections were treated with formic acid and subsequently separated with heavy liquid. More than a thousand conodont elements were recovered. Most of them are the platform elements. Ramiform elements are rare.

Twenty-three conodont species belonging to nine genera were identified. Several platform elements are in open nomenclature. The studied interval is characterized by rather rich taxonomically and numerically conodont association, in which the idiognathoidids dominate (Tables 1,2,3). The most conservative species Idiognathoides sinuatus $(=I d$. corrugatus) and Id. sulcatus sulcatus are known from the beginning of the Bashkirian and dominate throughout the Bashkirian and early Moscovian in the Donets Basin. The majority of idiognathoidids in the Donets Basin became extinct by the top of the Kam'iankian Horizon of the lower Lozovian. Idiognathoides sinuatus, Id. sulcatus, Id. tuberculatus Nemirovskaya in Kozitskaya et al., 1978, Id. lanei Nemirovskaya in Kozitskaya et al., Id. fossatus [= Id. ouachitensis (Harlton, 1933)], are characteristic of the uppermost Bashkirian (all limestones of the $\mathrm{C}_{2}{ }^{4}$ (I) Suite) and Id. postsulcatus of the $\mathrm{C}_{2}{ }^{5}(\mathrm{~K})$ Suite.

The species of the Declinognathodus are common in the Lower Pennsylvanian. They dominate in different parts of Bashkirian and lower Moscovian. Their importance for biostratigraphy is difficult to overestimate. The midCarboniferous or Mississippian-Pennsylvanian boundary is defined by the evolutionary appearance of $D$. noduliferus s. 1. (Lane et al., 1985, 1999; Nemirovskaya, 1982; Nemyrovska, 1999). A few specimens of $D$. noduliferus occur for the last time in the basal beds of the $\mathrm{C}_{2}{ }^{4}$ (I) Suite (limestone $\mathrm{I}_{2}$ ). In the Bashkirian-Moscovian boundary interval, the youngest species of Declinognathodus represented by the $D$. marginodosus and $D$. donetzianus. The lineage $D$. noduliferus $-D$. marginodosus $-D$. donetzianus is well documented in the Zolota Valley (Nemyrovska, 1999) and Malo-Mykolaivka sections (Ueno \& Nemyrovska, 2008; Nemyrovska et al., 2010) (Figs 3-4, 6).

The species of Idiognathodus occurring in the Bashkirian-Moscovian boundary interval are: I. sinuosus, I. incurvus Dunn, 1966, I. aljutovensis Alekseev et al., 1994, I. volgensis Alekseev et al., 1994 and a number of species in the open nomenclature. The entry of genus Idiognathodus is recorded in the mid-Bashkirian in the Donets Basin and in a whole Europe and China.

The Neognathodus species are not common in the Bashkirian-Moscovian boundary interval. These are as follows: N. kanumai Igo, 1974, N. atokaensis, $N$. aff. $N$. bothrops, $N$. aff. $N$. caudatus Lambert, 1992, and some forms in open nomenclature. Among others, $N$. atokaensis is more common and first recorded at the top of the studied interval (Table 3).

In the lower part of the Moscovian, i.e., the lower part of the Lozovian Regiostage or $\mathrm{C}_{2}{ }^{5}(\mathrm{~K})$ Suite, the first species of the genera Diplognathodus and Mesogondolella were recorded. The FOD of Di. ellesmerensis is in limestone $\mathrm{K}_{3}$ of the Zolota Valley section. A currently lost specimen of Di. coloradoensis (Murray \& Chronic, 1965) (or Di. aff. Di. coloradoensis) was previously found in limestone $\mathrm{I}_{3}$ of the Malo-Mykolaivka section. FOD of Mesogondolella donbassica is registered in limestone $\mathrm{K}_{6}{ }^{3}$. These species are rare in this part of the Moscovian. They are widely distributed and are successfully used for correlation by their occurrence.

\subsection{Systematic palaeontology}

Only the most stratigraphically important species (platform elements) for the Bashkirian-Moscovian boundary are described here.

Family Gnathodontidae Sweet, 1988

Genus Declinognathodus Dunn, 1966 
Type species Cavusgnathus nodulifera Ellison \& Graves, 1941 [according to the first description (identification)]; lower Pennsylvanian (Morrowan) of North America.

Declinognathodus donetzianus Nemirovskaya, 1990 (Figs 9K-9M, 9Q)

1984 Declinognathodus noduliferus, Goreva, pl. 1, figs $15 \mathrm{~b}, 16,22-23$ (non cet.).

1985 Idiognathoides tuberculatus, van den Boogaard $\&$ Bless, pl. 8, fig. 8 (non cet.).

1985 Idiognathoides sulcatus, Savage \& Barkelly, p. 1467, figs 10.1-10.4, 10.9-10.12 (non cet.).

1990 Declinognathodus donetzianus, Nemirovskaya, p. 40, pl. 1, figs 1-4.

1999 Declinognathodus donetzianus, Nemyrovska, p. 53, pl. 2, figs 7, 9, 14 .

1999 Declinognathodus donetzianus, Nemyrovska et al., fig. 3.2.

2001 Declinognathodus donetzianus, Alekseev \& Govera, p.116, pl. 13, fig. 26; pl. 14, figs 9-11.

2006. Declinognathodus donetzianus, Pazukhin et al., p. 18, fig. 1 .

2009 Declinognathodus donetzianus, Kulagina et al., pl. 8, figs. 2-3.

2010 Declinognathodus donetzianus, Nemyrovska et al., fig. 3.2.

2012 Declinognathodus donetzianus, Work et al., fig. 8.1 .

2017 Declinognathodus donetzianus, Nemyrovska, pl. 2, figs $22-23$.

Material. 65 specimens.

Holotype. IGS NASU, No. 597a-1, Ukraine, Donets Basin, Lugansk County, Lutugino district, the Olkhova River, Pashenna Valley, Moscovian Stage, Lozovian Regiostage, $\mathrm{C}_{2}{ }^{5}(\mathrm{~K})$ Suite, limestone $\mathrm{K}_{6}$ (Nemirovskaya, 1990, pl. 1, fig. 1).

Diagnosis. $\mathrm{P}_{1}$ elements of arrow-like shape, elongated, narrow. Carina is short, it declines to the rostral parapet in a ventral quarter of the platform. This parapet is reduced down to several nodes. The ventral one or two nodes are parallel to the axis of element, the rest node/nodes declines rostrally and are located up to almost perpendicular to the platform axis or under the acute angle to it.
Description. The free blade connects to the oblong narrow platform in the middle position and passes into a short carina that declines to the rostral parapet in the ventral quarter of the platform. The degree of declination of the carina varies. The ventral part of the rostral parapet is reduced to 3-6 nodes. Ventral one or two nodes are parallel to the axis of the element, the rest are deflected outwards and are located perpendicular to the axis of the element or at an angle to it (Figs 9K-9M, 9Q).

The deflecting nodes are usually discrete. Short carina is nodular, sometimes represented by merged nodes and looks like a longitudinal rib. The caudal parapet is also nodular, the distances between the nodes increase on the parapets towards the dorsal end.

Remarks. The main difference from the closely related Declinognathodus marginodosus and the group of species $D$. noduliferus is the presence of deflection of the rostral reduced parapet rostrally at an angle to the longitudinal axis of the element and the associated additional nodes on the rostral side of the platform. The illustrated specimens of D. donetzianus from the Moscow Syneclise (Alekseev \& Goreva in Makhlina et al., 2001, pl. 13, figs 26; pl. 14, figs 9-11) are almost identical to our specimens. In general, the conodont association of early Lozovian (early Moscovian) of the Donets Basin is very similar to the early Vereian conodonts of the Moscow Basin. The illustrated specimens of $D$. donetzianus from the Volga-Ural region (see Sungatullina, 2014, text-figs 11-13) are similar to ours. The first author has examined the specimens illustrated by van den Boogaard \& Bless (1985, pl. 8, fig. 8) from the Bolsovian of Western Europe and considered that those specimens belong to $D$. donetzianus as well. As to the illustrated specimens of $D$. donetzianus from the Basu section, South Urals (Kulagina et al., 2009, pl. 8, figs 2-3), but the presence of the rostrally deflected nodes permits to refer them to $D$. donetzianus although their ventral part including carina and free blade is broken. One specimen of D. donetzianus from the lower Atokan of the Appalachian Basin in the eastern U.S.A. (Work et al., 2012, fig. 8.1) displays main features of $D$. donetzianus, however, it is not identical to the typical ones from the Donets Basin by a thick ridge (not additional nodes) deflected rostrally on the ventral part of the expansion of the basal cavity.

Range. Middle Pennsylvanian - the lower part of the Moscovian Stage, the Vereian Substage (Horizon) of Russia (Moscow Syneclise, the South Urals, Volga-Urals region), Ukraine (the Donets Basin), the lower part of the Bolsovian Stage (Aegiranum marine Band) of Great Britain, the upper part of the Atokan of North America (Alaska).

Occurrence. The lower part of the lower Moscovian Stage (lower Lozovian, the $\mathrm{C}_{2}^{5}(\mathrm{~K})$ Suite, limestones $\mathrm{K}_{1}$ - 


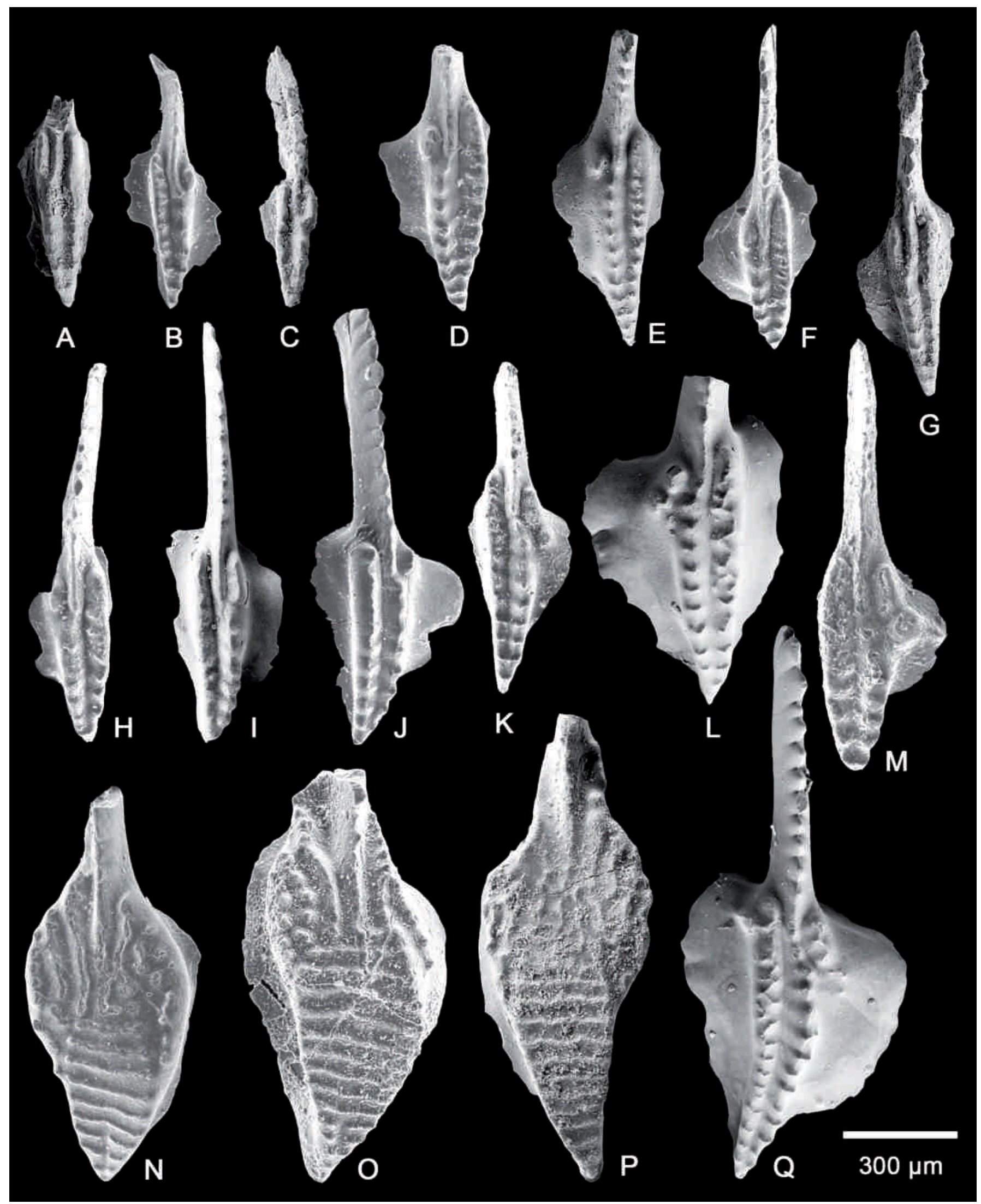


$\mathrm{K}_{7}$ of the Donets Basin. The FAD of Declinognathodus donetzianus was recorded first at limestone $\mathrm{K}_{3}$ in the Karaguz section, later 10 specimens were found in limestone $\mathrm{K}_{2}$ of the Karaguz and 7 specimens in the Zolota Valley section. After 1999 single specimens of $D$. donetzianus were found at the top of limestone $\mathrm{K}_{1}$ in the Zolota and Malo-Mykolaivka sections. Declinognathodus donetzianus occurs in every limestone up to limestone $\mathrm{K}_{7}$.

Declinognathodus marginodosus (Grayson, 1984) (Figs 9A-9J)

1978 Declinognathodus noduliferus, Nemirovskaya in Kozitskaya et al., p. 30, pl. 25, figs 10-14 (non cet.).

1981 Declinognathodus noduliferus inaequalis, Méndez \& Menéndez-Álvarez, fig. 3.1.

1981 Declinognathodus noduliferus noduliferus, Méndez \& Menéndez-Álvarez, fig. 3.2.

1984 Idiognathoides marginodosus, Grayson, 50, pl. 1, figs 3-4, 7, 9-11, 13-14 (non figs 16, $18=$ Idiognathoides sulcatus); pl. 2 figs 8, 9, 17 (non fig. $4=I d$. sulcatus)

1984 Declinognathodus noduliferus, Goreva, pl. 1, figs $14,17-21$.

1990 Declinognathodus marginodosus,

Nemirovskaya, 42, pl. 1, figs 5-11.

1990 "Declinognathodus" marginodosus, Grayson et al., 365, pl. 1, fig. 28 (non cet.).

1992 Declinognathodus marginodosus, Sutherland \& Grayson, pl. 2, fig. 11.

1993 Declinognathodus marginodosus, Nemirovskaya \& Alekseev, pl. 3, figs 5-6.

1995 Declinognathodus marginodosus, Nemirovskaya \& Alekseev, pl. 1, figs 9-10.
1999 Declinognathodus marginodosus, Nemyrovska, p. 54, pl. 2, figs 2, 8, 11-12, 17.

1999 Declinognathodus marginodosus, Nemyrovska et al., fig. 3.8.

2001 Declinognathodus marginodosus, Alekseev \& Goreva in Makhlina et al., p. 117. pl. 13, figs 21-25; pl. 14, figs 4-6.

2009 Declinognathodus marginodosus, Kulagina et al., pl. 8, fig. 1 .

2010 Declinognathodus marginodosus, Nemyrovska et al., fig. 3.2.

2016 Declinognathodus marginodosus, Qi et al., figs. 9D-9F, 9K

2017 Declinognathodus marginodosus, $\mathrm{Hu}$ et al., figs $4 \mathrm{R}, 4 \mathrm{~S}$.

2017 Declinognathodus marginodosus, Nemyrovska, pl. 2 figs $20-21$

Material. 423 specimens.

Holotype. OU7151 (sample No. 274-17C), U.S.A., Arbuckle Mountains, Southern Oklahoma, Atokan Stage, Pennsylvanian, Atoka Formation (Grayson, 1984, pl. 1, fig. 13).

Diagnosis. The platform is elongated, narrow, with a pointed dorsal end. A short carina declines to the rostral parapet and merges with it in the ventral quarter of the platform. The reduced ventral part of the rostral parapet is represented by a node or a short longitudinal ridge and is isolated from the rest of the parapet-carina. The median groove is wide and deep.

Remarks. The majority of specimens in our collection and those illustrated from the other area have a distinct

Figure 9. Declinognathodus and Idiognathodus species from the studied sections. All specimens are with the same magnification; scale bar $=300 \mu \mathrm{m}$. a) Declinognathodus marginodosus Grayson, 1984, IGSU-0914, Limestone K, Pashenna Valley section. b) Declinognathodus marginodosus Grayson, 1984, IGSU-0935, Limestone $\mathrm{K}_{1}$, Malo-Mykolaivka section. c) Declinognathodus marginodosus Grayson, 1984, IGSU-0936, Limestone $\mathrm{K}_{3}$, Karaguz Valley section. d) Declinognathodus marginodosus Grayson, 1984, IGSU-0937, Limestone $\mathrm{K}_{2}$, Malo-Mykolaivka section. e) Declinognathodus marginodosus Grayson, 1984, IGSU-0915, Limestone $\mathrm{K}_{2}$, Zolota Valley section. f) Declinognathodus marginodosus Grayson, 1984, IGSU-0890, Limestone $\mathrm{K}_{1}$, Malo-Mykolaivka section. g) Declinognathodus marginodosus Grayson, 1984, IGSU-0916, Limestone $\mathrm{K}_{4}$, Pashenna Valley section. h) Declinognathodus marginodosus Grayson, 1984, IGSU-0891, Limestone I, Malo-Mykolaivka section. i) Declinognathodus marginodosus Grayson, 1984, IGSU-0918, Limestone $\mathrm{K}_{5}$, Pashenna Valley section. j) Declinognathodus marginodosus Grayson, 1984, IGSU-0892, Limestone $\mathrm{K}_{1}$, Malo-Mykolaivka section. k) Declinognathodus donetzianus Nemirovskaya, 1990, IGSU-0853, Limestone $\mathrm{K}_{1}$, Malo-Mykolaivka section. I) Declinognathodus donetzianus Nemirovskaya, 1990, IGSU-0938, Limestone K, Pashenna Valley section. m) Declinognathodus donetzianus Nemirovskaya, 1990, IGSU0852, Limestone $\mathrm{K}_{2}$, Zolota Valley section. n) Idiognathodus aljutovensis Alekseev et al., 1994, IGSU-0939, Limestone $\mathrm{K}_{1}$, Malo-Mykolaivka section. o) Idiognathodus aljutovensis Alekseev et al., 1994, IGSU-0940, Limestone K 1 , Malo-Mykolaivka section. p) Idiognathodus aff. I. volgensis Alekseev et al., 1994, IGSU-0910, Limestone $\mathrm{K}_{3}$, Karaguz Valley section. q) Declinognathodus donetzianus Nemirovskaya, 1990, IGSU-0941, Limestone $\mathrm{K}_{6}$, Pashenna Valley section. 


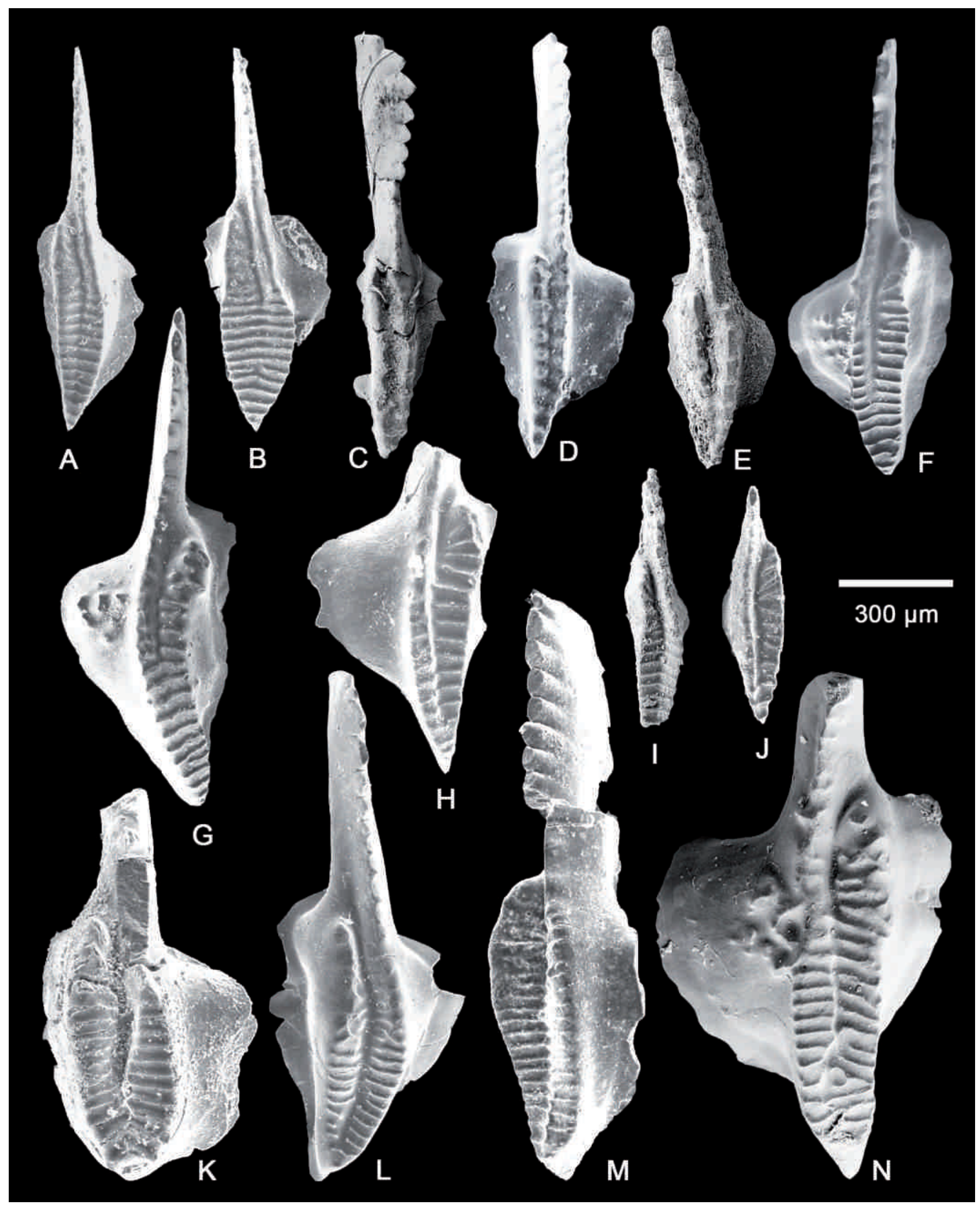


isolation of a node or ridge in the ventral part of a rostral parapet. But there occur the morphs with the node or ridge connected to the rest of the parapet or not isolated completely. By the other features they are a part of population of D. marginodosus (Figs 9G, 9I).

Declinognathodus marginodosus differs from $D$. noduliferus s. 1. by having a distinct isolation of a large node that is a reduced ventral part of the rostral parapet, a smooth, strong carina and larger distances between the nodes on the parapets. Declinognathodus marginodosus differs from the very similar $D$. donetzianus in the absence of rostrally deflected additional nodes located at an angle to the rostral parapet on the rostral platform expansion.

Range. The uppermost part of the Bashkirian Stagelower part of the Moscovian Stage of Europe and Asia. Upper part of the Morrowan - Atokan of North America.

Occurrence. Upper part of the upper Bashkirian (Upper Kayalian)- lower part of the lower Moscovian Lower Lozovian, $\mathrm{C}_{2}{ }^{4}(\mathrm{I})-\mathrm{C}_{2}{ }^{5}(\mathrm{~K})$ suites, limestones $\mathrm{I}_{2}-\mathrm{K}_{6}$ of the Donets Basin.

Genus Idiognathoides Harris \& Hollingsworth, 1933

Type species Idiognathoides sinuata Harris \& Hollingsworth, 1933 (according to the first designation); Lower Pennsylvanian (Morrowan) of North America.

Idiognathoides postsulcatus Nemyrovska, 1999.

(Fig. 10D)

1964 Gnathodus opimus, Igo \& Koike, 189, pl. 28, figs 15-17 (only).

1965 Gnathodus opimus, Igo \& Koike, 89, pl. 9, figs 1-3 (only).

1980 Gnathodus opimus sensu lato Morphotype 1, Bender, p. 12-13, pl. 2, figs 8-9, 15-16, 23-24, 29-31, $34,38$.
1981 Idiognathoides sulcatus sulcatus, Méndez \& Menéndez-Álvarez, fig. 3.7.

1984 Idiognathoides marginodosus morphotype C, Grayson, 50, pl. 1, figs 16, 18; pl. 2, fig. 19; pl. 3, figs 4, 10, 12, 14; pl. 4, figs 16, 21, 23.

1985 Idiognathoides sulcatus, van den Boogaard \& Bless, p. 150, fig. 9: 6-7.

1985 Idiognathoides sulcatus, Savage \& Barkeley, p. 1467-1469, fig. 10: 5-8 (only).

1995 Idiognathoides sulcatus, Nemirovskaya \& Alekseev, pl. 1, fig. 19 (only).

1999 Idiognathodus postsulcatus, Nemyrovska, p. 68 , pl. 3, figs 9,18 .

1999 Idiognathodus postsulcatus, Nemyrovska et al., fig. 3.3.

2016 Idiognathodus postsulcatus, Qi et al., figs $11 \mathrm{~K}-11 \mathrm{M}$.

2017 Idiognathodus postsulcatus, Hu et al., figs 5F$5 \mathrm{G}$.

2017 Idiognathodus postsulcatus, Nemyrovska, pl. 2, figs $18,19$.

Material. 24 specimens.

Holotype. IGSU-Pash-1, Ukraine, Donets Basin, Lugansk County, Lutugino district, the Olkhova River, Pashenna Valley, Moscovian Stage, Lozovian Regiostage, $\mathrm{C}_{2}{ }^{5}(\mathrm{~K})$ Suite, limestone $\mathrm{K}_{6}$ (Nemyrovska, 1999, pl. 3, fig.18).

Diagnosis. $\mathrm{P}_{1}$ elements with long nodular parapets of equal height and narrow and shallow groove between them. The nodes of the parapets are tightly spaced. Both platform sides asymmetrically convex.

Figure 10. Idiognathoides species from the studied sections. All specimens are with the same magnification; scale bar $=300 \mu \mathrm{m}$. a) Idiognathoides corrugatus (Harris \& Hollingsworth, 1933), IGSU-0901, Limestone $\mathrm{I}_{2}{ }^{1}$, Malo-Mykolaivka section. b) Idiognathoides corrugatus (Harris \& Hollingsworth, 1933), IGSU-0911, Limestone $\mathrm{K}_{1}$, Malo-Mykolaivka section. c) Idiognathoides aff. postsulcatus Nemyrovska, 1999, IGSU-0917, Limestone $\mathrm{K}_{2}$, Zolota Valley section. d) Idiognathoides postsulcatus Nemyrovska, 1999, IGSU-Pash-1, Limestone $\mathrm{K}_{6}$, Pashenna Valley Section. e) Idiognathoides aff. postsulcatus Nemyrovska, 1999, IGSU-0929, Limestone $\mathrm{K}_{2}$, Zolota Valley section. f) Idiognathoides tuberculatus Nemirovskaya in Kozitskaya et al., 1978, IGSU-597a/7, Limestone $\mathrm{K}_{6}$, Pashenna Valley section. g) Idiognathoides tuberculatus Nemirovskaya in Kozitskaya et al., 1978, IGSU-0903, Limestone $\mathrm{I}_{3}$, Malo-Mykolaivka section. h) Idiognathoides sinuatus Harris \& Hollingsworth, 1933, IGSU-0902, Limestone $\mathrm{I}_{3}$, Malo-Mykolaivka section. i) Idiognathoides corrugatus (Harris \& Hollingsworth, 1933), IGSU-0930, Limestone $\mathrm{K}_{2}$, Zolota Valley section. j) Idiognathoides sinuatus Harris \& Hollingsworth, 1933, IGSU-0931 Limestone K, Malo-Mykolaivka section. k) Idiognathoides fossatus (Branson \& Mehl, 1941), IGSU0932, Limestone I , Malo-Mykolaivka section. I) Idiognathoides fossatus (Branson \& Mehl, 1941), IGSU-0904, Limestone $\mathrm{K}_{1}$, Malo-Mykolaivka section. m) Idiognathoides fossatus (Branson \& Mehl, 1941), IGSU-0933, Limestone $\mathrm{I}_{3}$, MaloMykolaivka section. n) Idiognathoides tuberculatus Nemirovskaya in Kozitskaya et al., 1978, IGSU-0934, Limestone I, Malo-Mykolaivka section. 


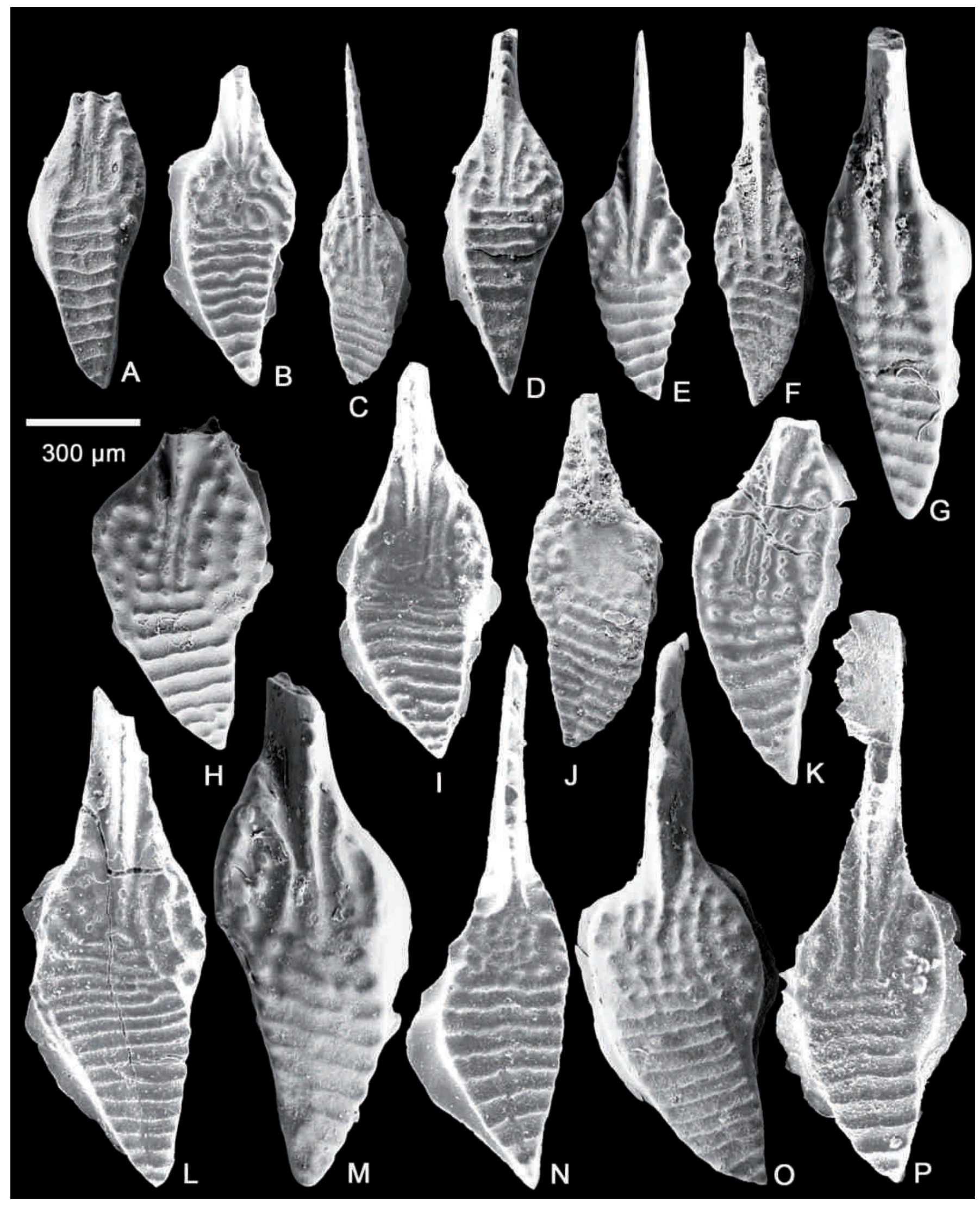


Description. $\mathrm{P}_{1}$ elements are straight, narrow, elongated, sometimes they are slightly curved caudally. The parapets are equal in height and separated mostly by narrow and shallow groove. Both sides of platform are asymmetrical and very convex. The greater convexity is in the ventral part of the platform. The blade and the platform are almost of equal length. In our small collection only dextral elements were found.

Remarks. Idiognathoides postsulcatus is very similar to its ancestor Id. sulcatus sulcatus and was assigned to the latter as a rule. Nevertheless Id. postsulcatus differs from its ancestor by its longer parapets, narrower platform, very asymmetrical convex platform sides. 2 specimens (Figs 10C, 10E) were identified as $I d$. aff. $I d$. postsulcatus. The main reason why they are not assigned to Id. postsulcatus is presence of wide and rather deep groove. The latter features make them closer to Id. sulcatus sulcatus. Idiognathoides postsulcatus differs from Id. sulcatus parvus by equal length of parapets and very convex platform sides.

Range. Lower Moscovian of Donets Basin, Ukraine, Urals, Russia (Nemirovskaya \& Alekseev, 1995), Omi and Akioshi Limestones, Japan (Igo \& Koike, 1964). It was found in the Cantabrian Mountains, Spain (Méndez \& Menéndez-Álvarez, 1981), Atokan, North America (Sverdrup Group of the Canadian Arctic (Bender, 1980), and Arbuckle Mountains, Oklahoma (Grayson, 1984), Klavak Formation of Alaska (Savage \& Barkeley, 1985), North America, Aegiranum marine Band, basal Bolsovian of Western Europe (van den Boogaard \& Bless, 1985) and upper Bashkirian and lower Moscovian of China (Qi et al., 2016; Hu et al., 2017).

Occurrence. Lower part of the Moscovian, lower part of the Lozovian, $\mathrm{C}_{2}^{5}(\mathrm{~K})$ Suite, limestones $\mathrm{K}_{2}-\mathrm{K}_{6}$ of the Karaguz and Pashenna Valley, Donets Basin.

Family Sweetognathidae Ritter, 1986
Genus Diplognathodus Kozur \& Merrill in Kozur, 1975

Type species Spathognathodus coloradoensis Murray \& Chronic, 1965 (according to the first designation); Pennsylvanian, Demoinsian of North America.

Diplognathodus ellesmerensis Bender, 1980

(Figs 12G, 12H)

1980 Diplognathodus ellesmerensis, Bender, p. 9, pl. 4, figs 5-7, 11, 15-21, 23-25.

1985 Diplognathodus ellesmerensis, van den Boogaard \& Bless, p. 23, pl. 1, fig. A.

1999 Diplognathodus ellesmerensis, Nemyrovska, pl. 11, figs 14,15

1999 Diplognathodus ellesmerensis, Nemyrovska et al., fig. 6.6.

2001 Diplognathodus ellesmerensis, Goreva \& Alekseev in Makhlina et al., p. 116, pl. 14, fig. 17; pl. 17, fig. 21.

2003 Diplognathodus ellesmerensis, Wang \& Qi, pl. 4 , figs $6,7$.

2004 Diplognathodus ellesmerensis, Wang et al., pl. 3, fig. 8 .

2007 Diplognathodus ellesmerensis, Nemyrovska in Fohrer et al., figs 15.2, 15.4, 15.7.

2016 Diplognathodus ellesmerensis, Qi et al., figs $7 \mathrm{~A}, 7 \mathrm{~B}$

2016 Diplognathodus ellesmerensis, Scomazzon et al., figs. 10.27-10.31.

2017 Diplognathodus ellesmerensis, Nemyrovska, pl. 3 , figs 10-11.

2017a Diplognathodus ellesmerensis, Cardoso et al., p. 81 , fig. 4.13 .

Figure 11. Idiognathodus species from the studied sections. All specimens are with the same magnification; scale bar $=300 \mu \mathrm{m}$. a) Idiognathodus sp., IGSU-0945, Limestone $\mathrm{K}_{3}$, Karaguz Valley section. b) Idiognathodus sp., IGSU-0946, Limestone $\mathrm{I}_{2}$, Malo-Mykolaivka section. c) Idiognathodus aljutovensis Alekseev et al., 1994, IGSU-0907, Limestone $\mathrm{K}_{5}$, Karaguz Valley section. d) Idiognathodus sp., IGSU-0947, Limestone $\mathrm{K}_{3}$, Karaguz Valley section. e) Idiognathodus sp., IGSU0948, Limestone $\mathrm{K}_{6}$, Pashenna Valley section. f) Idiognathodus sp., IGSU-0949, Limestone $\mathrm{K}_{3}$, Karaguz Valley section. g) Idiognathodus sp., IGSU-0909, Limestone $\mathrm{K}_{6}$, Pashenna Valley section. h) Idiognathodus aljutovensis Alekseev et al., 1994, IGSU-0950, Limestone K, Pashenna Valley section. i) Idiognathodus sinuosus Ellison \& Graves, 1941, IGSU-0892, Limestone $\mathrm{I}_{3}$, Malo-Mykolaivka section. j) Idiognathodus aljutovensis Alekseev et al., 1994, IGSU-0908, Limestone $\mathrm{K}_{5}$, Karaguz Valley section. k) Idiognathodus aljutovensis Alekseev et al., 1994, IGSU-0893, Limestone I, Malo-Mykolaivka section. I) Idiognathodus sinuosus Ellison \& Graves, 1941, IGSU-0900, Limestone I, Malo-Mykolaivka section. m) Idiognathodus sp. A Grubbs, 1984, IGSU-0913, Limestone $\mathrm{K}_{6}^{3}$, Karaguz Valley section. n) Idiognathodus sp., MN-30, IGSU-0927, Limestone $\mathrm{K}_{1}$, Malo-Mykolaivka section. o) Idiognathodus volgensis Alekseev et al., 1994, IGSU-0912, Limestone $\mathrm{K}_{5}$, Karaguz Valley section. p) Idiognathodus aljutovensis Alekseev et al., 1994, IGSU-0931, Limestone $\mathrm{K}_{1}$, Zolota Valley section. 


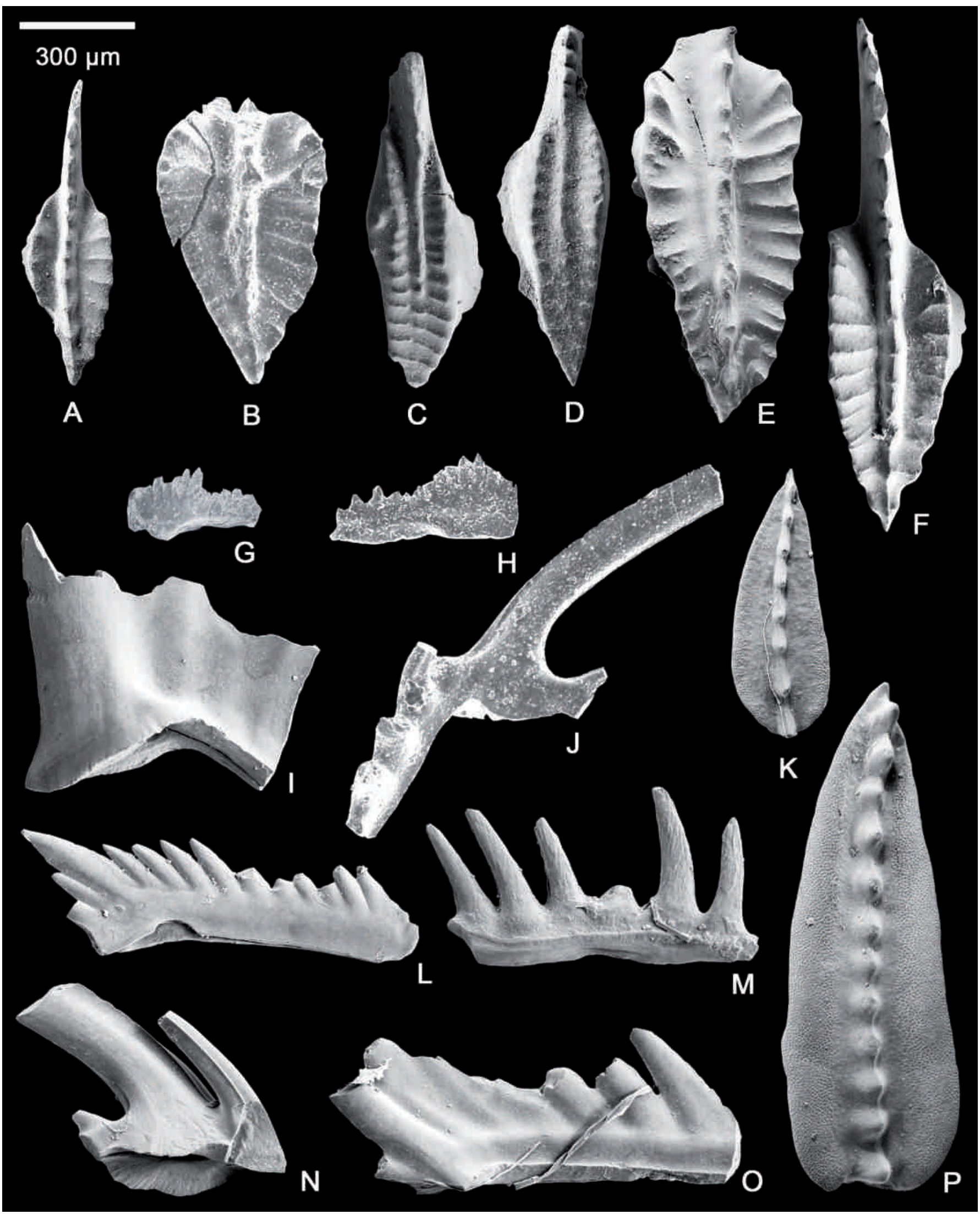


2017b Diplognathodus ellesmerensis, Cardoso et al., pl. 1, fig. 11.

Material. 11 specimens.

Holotype. GSC, № 49280, Canadian Arctic, Elsmere Island, Middle Pennsylvanian, lower part of the Khea-fiord Formation (Bender, 1980, pl. 4, figs 23-25).

Diagnosis. Small $\mathrm{P}_{1}$ elements with low subelliptical platform (cup) and high free blade. Carina and blade are decorated by denticles. Between blade and platform there is a distinct notch with several small denticles.

Description. $\mathrm{P}_{1}$ elements of small size. The platform (cup) with is low, subelliptical, enlarged. The blade is twice or three times higher than the platform, it is ornamented by 5-7 laterally compressed denticles. Carina is covered by rounded unequally high 4-6 denticles. Some of them are tilted forwards. The distance between them is unregular. A distinct notch located between the blade and carina bears several very small denticles. Basal cavity is wide, symmetrical, occupies about three quarter of element length.

Remarks. Diplognathodus ellesmerensis differs from the close Di. orphanus by longer platform and larger basal cavity, higher denticles of free blade, their different shape and by presence of notch between blade and platform. It differs from Di. coloradoensis by having a longer platform and by different shape and order of the denticles on carina and also by different height of the blade and carina.

Range. Diplognathodus ellesmerensis is widely distributed. It is common in the Atokan of North America, Canadian Arctic and lower Moscovian of Europe and Asia (Moscow Syneclise and Urals of Russia; Donets Basin of Ukraine; Cantabrian Mountains of Spain and South China).
Occurrence. Lower Moscovian, lower part of the Lozovian Regiostage, $\mathrm{C}_{2}{ }^{5}(\mathrm{~K})$ Suite, limestone $\mathrm{K}_{3}$ of the Zolota Valley section and limestones $\mathrm{K}_{3}-\mathrm{K}_{6}{ }^{3}$ of the Karaguz and Pashenna Valley, Donets Basin.

\subsection{Biostratigraphy of the Bashkirian- Moscovian boundary beds by conodonts}

Analysis of the conodont distribution across the BashkirianMoscovian boundary in the Donets Basin resulted in recognition of several conodont zones in this interval. They are range zones that were established at the end of 1990s (Nemyrovska, 1999) and updated recently (Nemyrovska, 2017).

\subsubsection{Idiognathoides tuberculatus - Id. fossatus Zone (Figs 9-11)}

The lower boundary is defined by the FAD of the late representatives of the Idiognathoides species, Id. tuberculatus and Id. fossatus. The upper boundary is determined by the FAD of one of the late species of Declinognathodus - D. marginodosus.

The zone overlaps the interval of the greater part of the $\mathrm{C}_{2}{ }^{3}(\mathrm{H})$ Suite and the lower part of the $\mathrm{C}_{2}{ }^{4}$ (I) Suite, i.e., the interval between limestones $\mathrm{H}_{3}$ and $\mathrm{I}_{2}$. This interval corresponds to the middle part of the Kayalian Regiostage of the Bashkirian Stage of the Ukrainian Stratigraphic Scheme (Poletaev et al., 2013). It corresponds to the upper part of the Cheremshanian Substage of the East European Platform (Resolution, 1990).

Besides the name bearers characteristic species in this zone are Idiognathoides sinuatus (Id. corrugatus), Id. sulcatus sulcatus, Id. sulcatus parvus, Id. lanei, Idiognathodus sinuosus, I. praedelicatus Nemyrovska, 1999, I. aljutovensis, "Streptognathodus" expansus, "S." suberectus Dunn, 1966 and others. Such species as "S." expansus and "S." suberectus were not found above limestone $\mathrm{I}_{1}$. Idiognathoides sinuatus (Id. corrugatus) dominates.

Figure 12. Neognathodus, Mesogondolella and Diplognathodus species and ramiforms from the studied sections. All specimens are with the same magnification; scale bar $=300 \mu \mathrm{m}$. a) Neognathodus sp., IGSU-0942, Limestone $\mathrm{K}_{6}$, Pashenna Valley section. b) Neognathodus aff. bothrops Merrill, 1972, IGSU-174-1, Limestone $\mathrm{K}_{2}$, Kholodna Valley section. c) Idiognathodus sp., IGSU-0925, Limestone $\mathrm{K}_{6}^{3}$, Pashenna Valley section. d) "Streptognathodus" transitivus Kossenko in Kozitskaya et al., 1978, IGSU-0854, Limestone $\mathrm{K}_{6}^{3}$, Pashenna Valley section. e) Neognathodus sp., IGSU-0943, Limestone $\mathrm{K}_{6}$, Pashenna Valley section. f) Neognathodus atokaensis Grayson, 1984, IGSU-0929, Limestone $\mathrm{K}_{6}$, Karaguz Valley section. g) Diplognathodus ellesmerensis Bender, 1980, IGSU-590-2, limestone $\mathrm{K}_{3}$, Zolota Valley section. h) Diplognathodus ellesmerensis Bender, 1980, IGSU-0851, Limestone $\mathrm{K}_{3}$, Malo-Mykolaivka section. i) Idioprioniodus conjunctus (Gunnell, 1931), M element, IGSU-0920, Limestone $\mathrm{K}_{6}^{3}$, Pashenna Valley section. j) DE - Ligonodina roundyi (Hass, 1953), IGSU-0924, Limestone $\mathrm{K}_{1}$, Zolota Valley section. k) Mesogondolella donbassica (Kossenko in Kozitskaya et al., 1978), IGSU-0944, limestone $\mathrm{K}_{6}$, Pashenna Valley section. I) Ozarkodina sp., IGSU-0921, Limestone $\mathrm{K}_{6}{ }^{3}$, Pashenna Valley section. m) Ubinates sp., IGSU-0919, Limestone $\mathrm{K}_{6}{ }^{3}$, Pashenna Valley section. n) DE - Roundya sp., IGSU-0923, Limestone $\mathrm{K}_{6}{ }^{3}$, Pashenna Valley section. o) DE - ?Ozarkodina sp., IGSU-0922, Limestone $\mathrm{K}_{6}^{3}$, Pashenna Valley section. p) Mesogondolella donbassica (Kossenko in Kozitskaya et al., 1978), IGSU-0926, limestone $\mathrm{K}_{6}$, Pashenna Valley section. 


\subsubsection{Declinognathodus marginodosus Zone} (Figs 9-11)

The lower boundary of the zone is defined by the FAD of Declinognathodus marginodosus. The upper boundary is determined by the FAD of the youngest species of the genus, $D$. donetzianus, which is a direct descendant of $D$. marginodosus.

This zone ranges from limestone $\mathrm{I}_{2}$ of the upper part of the $\mathrm{C}_{2}{ }^{4}$ (I) Suite up to limestone $\mathrm{K}_{1}$ of the $\mathrm{C}_{2}{ }^{5}(\mathrm{~K})$ Suite. This interval corresponds to the upper part of the Kayalian Regiostage of the Bashkirian Stage of the Ukrainian Stratigraphic Scheme (Poletaev et al., 2013). It corresponds to the Melekessian Substage of the Unified Scheme of the East European Platform. The lower boundary of this zone was lowered from limestone $\mathrm{I}_{3}$ down to limestone $\mathrm{I}_{2}$ since Declinognathodus marginodosus was found recently below the limestone I $_{3}$ boundary indicated by Nemyrovska (1999).

The conodont association consists mainly of Idiognathoides and Idiognathodus species that are most abundant in the underlying beds. These are Id. sinuatus, Id. fossatus, Id. tuberculatus, Id. lanei, I. sinuosus, I. praedelicatus, I. aljutovensis, I. incurvus and others. Idiognathoides sinuatus and Id. fossatus dominate. Idiognathoides corrugatus still occurs but its role is gradually reduced as it is supplanted by Id. fossatus. The index species $D$. marginodosus is found at every level but not in significant quantities.

\subsubsection{Declinognathodus donetzianus Zone (Figs 9-12)}

The lower boundary of the zone is defined by the FAD of Declinognathodus donetzianus. Its upper boundary is determined by the FOD of "Streptognathodus" transitivus and more advanced species of Neognathodus.

The zone overlaps the greater part of the lower $\mathrm{C}_{2}{ }^{5}$ (K) Suite. According to the Ukrainian Carboniferous Stratigraphic Scheme this interval corresponds to the uppermost part of the Kayalian Regiostage of the Bashkirian Stage and the lower part of the Lozovian Regiostage of the Moscovian Stage (Poletaev et al., 2013). It corresponds to the uppermost part of the Melekessian Substage and to the Vereian Substage of the Moscovian Stage of the East European Platform (Resolutions, 1990).

The characteristic zonal species are Id. sinuatus, Id. fossatus, and Id. tuberculatus, known from the previous zone, along with a new early Moscovian species, $I d$. postsulcatus. Declinognathodus marginodosus and D. donetzianus also play an essential role. Among the Idiognathodus species I. sinuosus, I. aljutovensis, I. praedelicatus, I. incurvus and I. volgensis still occur. Among the new elements, the FOD of Diplognathodus ellesmerensis (limestone $\mathrm{K}_{3}$ in the Zolota and Karaguz valleys) is important. It should be noted that one specimen of Diplognathodus aff. Di. coloradoensis was found in limestone $\mathrm{I}_{3}$. Unfortunately, it was lost during SEM photography. Additional collections are necessary to get more Diplognathodus specimens.

\subsection{4. "Streptognathodus" transitivus Zone (Figs 10-12)}

The lower boundary of the zone is defined by the FOD of "Streptognathodus" transitivus, which was found at the level of limestone $\mathrm{K}_{6}$. The origin of this species is not known. But discrete, characteristic features and persistent occurrence of this species in the lower Moscovian beds in the Donets Basin and Moscow Syneclise permitted us to distinguish the conodont zone.

Characteristic conodonts of this zone continue to be species of Idiognathoides: Id. sinuatus, Id. fossatus, Id. tuberculatus, Id. postsulcatus, and new taxa of Neognathodus: $N$. atokaensis and $N$. aff. $N$. bothrops, along with Diplognathodus coloradoensis and Mesogondolella donbassica. Species of Declinognathodus become extinct by that time.

\section{SUMMARY}

A fairly large variety of conodonts occurring in the Bashkirian-Moscovian boundary interval of the most complete sections in the Donets Basin allow us to refine the biostratigraphy of the above-mentioned deposits. Two conodont lineages established in the Donets Basin and proposed as potential markers for the definition of the Bashkirian-Moscovian boundary are better documented. The additional study has shown that in the Donets Basin, Moscow Syneclise and Urals only one lineage is acceptable with Declinognathodus donetzianus as a marker of the Bashkirian-Moscovian boundary but Idiognathoides postsulcatus was not found. Idiognathoides postsulcatus is distributed in Britain, Spain, China and North America. The entry of Id. postsulcatus in South China is much below the FOD of Diplognathodus ellesmerensis, another potential marker for the boundary, which occurs close to the traditional Bashkirian-Moscovian boundary. Numerous cosmopolitan species found in the Donets Basin are useful for correlation with other areas. This makes the study of Donets Basin conodonts important for establishing a Bashkirian-Moscovian boundary GSSP.

\section{ACKNOWLEDGEMENTS}

This study was supported by the Institute of Geological Sciences of the National Academy of Sciences of 
Ukraine (Project No. IV-1-13, State registration number 0113U000063). We thank Paul L. Brenckle for his helpful comments and corrections of English. We are grateful to the two reviewers, James E. Barrick and Alexander S. Alekseev, for their insightful suggestions that highly improved this paper. We also thank the editors for their patient assistance.

\section{REFERENCES}

Aisenverg, D.E., Babenko, A.M., Belenko, M.G., Bragin, Yu.M., Getman, V.G., Dedov, V.S., Konashev, V.G., Lagutina, V.V., Levenshtein, M., Makarov, I.A., Nagornyi, Yu.N., Nesterenko, L.P., Poletaev, V.I., Popov, V.S., Rotay, A.P., Sokolova, G.U., Fisunenko, O.P., Sharmanova, G.V. \& Schegolev, A.K. 1975. Guide to excursions through the Donets Basin. Nauka, Moscow, 1-360.

Alekseev, A.S. \& Goreva, N.V. 2001. Chapter 9. Conodonta. In: Middle Carboniferous of Moscow Syneclise (southern part). Volume 2. Biostratigraphy (eds. Makhlina, M.Kh., Alekseev, A.S., Goreva, N.V., Goryunova, R.V., Isakova, T.N., Kossovaya, O.L., Lazarev, S.S., Lebedev, O.A. \& Shkolin, A.A.). Scientific World, Moscow, 113-140 (in Russian).

Alekseev, A.S. \& Goreva, N.V. 2013. The conodont Neognathodus bothrops Merrill, 1972 as the marker for the lower boundary of the Moscovian Stage (Middle Pennsylvanian). In: The Carboniferous-Permian Transition (eds. Lucas, S.G., DiMichele, W.A., Barrick, J.E., Schneider, J.W. \& Spielmann, J.A.). New Mexico Museum of Natural History and Science, Bulletin 60, 1-6.

Alekseev, A.S. \& Task Group 2013. Report of the Task Group to establish a GSSP close to the existing BashkirianMoscovian boundary. Newsletter on Carboniferous Stratigraphy, 30, 39-42.

Alekseev, A.S. \& Task Group 2017. Report of the Task Group to establish a GSSP close to the existing BashkirianMoscovian boundary. Newsletter on Carboniferous Stratigraphy, 33, 16-18.

Alekseev, A.S., Barskov, I.S. \& Kononova, L.I. 1994. Stratigrafiya nizh-nemoskovskogo pod'yarusa (srednij karbon) Tsentral'noj Rossii pokonodontam. Vestnik Moskovskogo Universiteta, Seriya Geologicheskaya, 4, 33-46 (in Russian).

Bender, K.P. 1980. Lower and Middle Pennsylvanian conodonts from the Canadian Arctic Archipelago. Geological Survey of Canada, Otawa, Paper, 79-15.

Blanco-Ferrera, S. Sanz-López, J., Villa, E. \& Bahamonde, J. 2009. Distribución de conodontos en el intervalo del límite Bashkiriense/Moscoviense (Pensilvaniense, Carbonífero) en la sección de San Antolín-La Huelga (Zona Cantábrica). In: XXV Jornadas de la Sociedad Española de Paleontología, Ronda, 23-25 de septiembre, Libro de resúmenes (eds. Palmqvist, P. \& Pérez-Claros, J.A.). Universidad de Málaga, Málaga, 140-143.
Boogaard, M. van den \& Bless, M.J.M. 1985. Some conodont faunas from the Aegiranum Marine Band. Proceedings of the Koninklijke Nederlandse Akademie van Wetenschappen, 88, 133-154.

Branson, E.B. \& Mehl, M.G. 1941. New and little known Carboniferous conodont genera. Journal of Paleontology, $15,97-106$.

Cardoso, C.N., Sanz-López, J. \& Blanco-Ferrera, S. 2017a. Pennsylvanian conodonts from the Tapajós Group (Amazonas Basin, Brazil). Geobios, 50, 75-95; doi:10.1016/j.geobios.2017.02.004.

Cardoso, C.N., Sanz-López, J. \& Blanco-Ferrera, S. 2017b. Pennsylvanian conodont zonation of the Tapajos Group (Amazonas Basin, Brazil). Stratigraphy, 14, 35-58; doi:10.29041/strat.14.1-4.35-58.

Deprat, J. 1912. Étude géologique du Yun-Nan Oriental. Part 3. Étude des fusulinidés de Chine et d'Indochine et classification des calcaires à fusulines. Mémoires $d u$ Service Géologique de l'Indo-Chine, 1, 1-76.

Dunn, D.L. 1966. New Pennsylvanian platform conodonts from southwestern United States. Journal of Paleontology, 40, 1294-1303.

Ellison Jr., S.P. \& Graves Jr., R.W. 1941. Lower Pennsylvanian (Dimple limestone) conodonts of the Marathon Region, Texas. Missouri School of Mines and Metallurgy Bulletin, Technical Series, 14, 1-21.

Fissunenko, O.P. 1991. Zonal phytostratigraphic Scale of Lower and Middle Carboniferous of the Donets Basin. Geological Zhurnal, 3, 55-64 (in Russian).

Fohrer, B., Nemyrovska, T.I., Samankassou, E. \& Ueno, K. 2007. The Pennsylvanian (Moscovian) Izvarino section, Donets Basin, Ukraine: A multidisciplinary study on microfacies, biostratigraphy (Conodonts, Foraminifers, and Ostracodes), and paleoecology. Journal of Paleontology, 81, 1-85.

Goreva, N.V. 1984. Moscovian conodonts of the Moscow Syneclize. In: Paleontological Characteristic of the Types and Key Sections of the Moscow Syneclise (ed. Menner, V.V.). Moscow State University Press, Moscow, 44-122 (in Russian).

Grayson Jr., R.C. 1984. Morrowan and Atokan (Pennsylvanian) conodonts from the northeastern margin of the Arbuckle Mountains southern Oklahoma. In: The Atokan Series (Pennsylvanian) and Its Boundaries - A Symposium (eds. Sutherland, P.K. \& Manger, W.L.). Oklahoma Geological Survey Bulletin, 136, 41-63.

Grayson Jr, R.C., Merrill, G.K. \& Lambert, L.L. 1990. Carboniferous gnathodontid conodont apparatuses: evidence of a dual origin for Pennsylvanian taxa. Courier Forschungsinstitut Senckenberg, 118, 353-396.

Groves, J. \& Task Group 2003. Report from the Task Group to establish a GSSP close to the existing BashkirianMoscovian boundary. Newsletter on Carboniferous Stratigraphy, 21, 10.

Groves, J. \& Task Group 2004. Report from the Task Group to establish a GSSP close to the existing BashkirianMoscovian boundary. Newsletter on Carboniferous Stratigraphy, 22, 14. 
Groves, J. \& Task Group 2006. Report from the Task Group to establish a GSSP close to the existing BashkirianMoscovian boundary. Newsletter on Carboniferous Stratigraphy, 24, 6-7.

Grubbs, R.K. 1984. Conodont platform elements from the Wapanucka andAtoka Formation (Morrowan-Atokan) of the Mill Creek Syncline, Central Arbuckle Mountains, Oklahoma. In: The Atokan Series (Pennsylvanian) and Its Boundaries - A Symposium (eds. Sutherland, P.K. \& Manger, W.L.). Oklahoma Geological Survey Bulletin, 136, 65-80.

Gunnell, F.H. 1931. Conodonts from the Fort Scott Limestone of Missouri. Journal of Paleontology, 5, 244-252.

Harris, R.W. \& Hollingsworth, R.V. 1933. New Pennsylvanian conodonts from Oklahoma. American Journal of Science, 25, 193-204.

Harlton, B.H. 1933. Micropaleontology of the Pennsylvanian Johns Valley Shale of the Ouachita Mountains. Journal of Paleontology, 7, 3-29.

Hass, M.W. 1953. Conodonts of the Barnett Formation of Texas. U.S. Geological Survey Professional Paper, 243-F, 69-94.

Higgins, A.C. \& Bouckaert, J. 1968. Conodont stratigraphy and palaeontology of the Namurian of Belgium. Mémoires Explicatives, Cartes Géologiques et Minières de la Belgique, Bruxelles, 10, 1-64.

Hu, K.Y., Qi, Y.P., Wang, Q.L., Nemyrovska, T.I. \& Chen, J.T. 2017. Early Pennsylvanian conodonts from the Luokun section of Luodian, Guizhou, South China. Palaeoworld, 26, 64-82; doi:10.1016/j.palwor.2015.12.003.

Igo, H. 1974. Some Late Carboniferous conodonts from the Akiyoshi Lime-stone, southwest Japan. Bulletin of Tokyo Gakugei University, Series IV, Mathematics and Natural Sciences, 26, 230-238.

Igo, H. \& Koike, T. 1964. Carboniferous conodonts from the Omi limestone,Niigata Prefecture, central Japan (Studies of Asian conodonts, Part I). Transactions and Proceedings of the Palaeontological Society of Japan, New Series, 53, 179-193.

Igo, H. \& Koike, T. 1965. Carboniferous conodonts from Yobara, Akiyoshi Limestone, Japan (Studies of Asian conodonts, Part II). Transactions and Proceedings of the Palaeontological Society of Japan, New Series, 59, 83-91.

Kabanov, P. \& Alekseev, A.S. 2011. Progress in cyclothem/ sequence stratigraphy of type lower Moscovian succession of Moscow Basin, Russia. Newsletter on Carboniferous Stratigraphy, 29, 42-50.

Kireeva G.D. 1951. Stratigraphic position of the Moscow stage in the section of the Donets Basin (based on the distribution of fusulinides). Bjulleten' Moskovskogo Obščestva Ispytatelej Prirody / Otdel geologičeskij, 26, 35-51 (in Russian).

Kossenko, Z.A., 1975. New species of conodonts from deposits of the Moscovian Stage in the southwestern part of the Donets Basin. Geological Journal, 35, 126-133 (in Russian).

Kozitskaya, R.I., Kossenko, Z.A., Lipnjagov, O.M. \& Nemirovskaya, T.I. 1978. Carboniferous Conodonts of the Donets Basin. "Naukova Dumka", Kiev (in Russian).
Kozur, H.W. 1975. Beiträge zur conodontenfauna des Perm. Geologische Palaontologische Mitteilungen Innsbruck, 5, 1-44.

Kulagina, E.I. 2009. Evolution of the fusulinid Depratina in the Bashkirian-Moscovian interval. Palaeoworld, 18, 94101; doi:10.1016/j.palwor.2009.04.003.

Kulagina, E.I., Pazukhin, V.N. \& Davydov, V.I. 2009. Pennsylvanian biostratigraphy of the Basu River section with emphasis on the Bashkirian-Moscovian transition. In: Carboniferous type sections in Russia and potential global stratotypes. Proceedings of the International Field Meeting "The historical type sections, proposed and potential GSSPs of the Carboniferous in Russia." Southern Urals Session. Ufa-Sibai, 13-18 August, 2009 (eds. Puchkov, V.N., Kulagina, E.I., Nikolaeva, S.V. \& Kochetova, N.N.). Design Polygraph Service, Ltd., Ufa, 34-63 (in Russian and English).

Lambert, L.L. 1992. Atokan and basal Desmoinesian conodonts from central Iowa, reference area for the Desmoinesian Stage. In: Recent Advances in Middle Carboniferous Biostratigraphy (eds. Sutherland, P.K. \& Manger, W.L.). Norman, Oklahoma Geological Survey, Circular 94, 111-123.

Lane, H.R., Baesemann, J.F., Brenckle, P.L. \& West, R.R. 1985. Arrow Canyon, Nevada - A potential Mid-Carboniferous boundary stratotype. Dixième Congrès International de Stratigraphie et de Géologie du Carbonifère, Madrid 12-17 September 1983, Compte Rendu, 4, 429-440.

Lane, H.R., Brenckle, P.L., Baesemann, J.F. \& Richards, B.C. 1999. The IUGS boundary in the middle of the Carboniferous: Arrow Canyon, Nevada, USA. Episodes, 22, 272-283.

Lemos, V.B. 1992. Conodontes do Carbonifero das Bacias do Amazonas e Solimoes. Taxonomia, parte II. Pesquisas, 19, 120-131.

Makhlina, M.Kh., Alekseev, A.S., Goreva, N.V., Goryunova, R.V., Isakova, T.N., Kossovaya, O.L., Lazarev, S.S., Lebedev, O.A. \& Shkolin, A.A. (eds.) 2001. Middle Carboniferous of Moscow Syneclise (Southern Part). Volume 2. Biostratigraphy. Scientific World, Moscow (in Russian).

Méndez, C.A. \& Menéndez-Álvarez, J.R. 1981. Conodontos del Bashkiriense superior y Moscoviense inferior en una seccion de la Cordillera Cantabrica (NW de España). Trabajos de Geologia, 11, 129-134.

Merrill, G.K. 1972. Taxonomy, phylogeny, and biostratigraphy of Neognathodus in Appalachian Pennsylvanian rocks. Journal of Paleontology, 46, 817-829.

Murray, F.N. \& Chronic, J. 1965. Pennsylvanian conodonts and other fossils from insoluble residues of the Minturn Formation (Desmoinesian), Colorado. Journal of Paleontology, 39, 594-610.

Nemirovskaya, T.I. 1982. Conodonts near the Lower/ Middle Carboniferous boundary of Donets Basin. In: Biostratigraphic Data for a Mid-Carboniferous Boundary (eds. Ramsbottom, W.H.C., Saunders, B. \& Owens, B.). IUGS Subcommission on Carboniferous Stratigraphy, Leeds, 15-18. 
Nemirovskaya, T.I. 1990. The latest representatives of the Genus Declinognathodus (conodonts) in the boundary sediments of the Bashkirian and Moscovian stages of the Donbass basin Carboniferous. Paleontologischeski Zbornik, 27, 39-43 (in Russian).

Nemirovskaya, T.I. \& Alekseev, A.S. 1993. Bashkirian conodonts of Askyn section (Mountain Bashkira). Bulletin de la Société Belge de Géologie, 68, 65-86 (in Russian).

Nemirovskaya, T.I. \& Alekseev, A.S. 1995. The Bashkirian conodonts of the Askyn Section, Bashkirian Mountains, Russia. Bulletin of the Belgium Geological Society, 103, 109-133.

Nemyrovska, T.I. 1999. Bashkirian conodonts of the Donets Basin, Ukraine. Scripta Geologica, 119, 1-115.

Nemyrovska, T.I. 2017. Late Mississippian-Middle Pennsylvanian conodont zonation of Ukraine. Stratigraphy, 14, 299-318.

Nemyrovska, T.I., Matsunaga, M. \& Ueno, K. 2010. Conodont and fusuline composite biostratigraphy across the Bashkirian-Moscovian boundrary in the Donets Basin, Ukraine: the Malo-Nikolaevka section. Newsletter on Carboniferous Stratigraphy, 28, 60-67.

Nemyrovska, T.I., Perret-Mirouse, M.F. \& Alekseev, A.S. 1999. On Moscovian (Late Carboniferous) conodonts of the Donets Basin, Ukraine. Neues Jahrbuch für Geologie und Paläontologie-Abhandlungen, 214, 169-194.

Nikitin, S.N. 1890. Carboniferous deposits of the Moscow region and artesian waters in the vicinity of Moscow. Transactions Geological Committee, 5, 1-182 (in Russian).

Pazukhin, V.N., Alekseev, A.S., Goreva, N.V. \& Kulagina, E.I. 2006. Discovery of potential Bashkirian-Moscovian boundary marker conodont Declinognathodus donetzianus in South Urals. Newsletter on Carboniferous stratigraphy, 24, 18-19.

Poletaev, V.I., Vdovenko, M.V., Shulga, V.F., Nemyrovska, T.I., Shchogolev, A.K. \& Boyarina, N.I. 2013. Chapter 7. Carboniferous System. In: Stratigraphy of Upper Proterozoic, Paleozoic and Mesozoic of Ukraine. Volume 1 (ed. Gozhik, P.F.). Upper Paleozoic of Ukraine (ed. Poletaev, V.I.). Kiev, IGS NAS, Logos, 247-356 (in Ukrainian).

Popov, A.V. 1979. Carboniferous Ammonoids of Donbas and Their Stratigraphic Significance. Nedra, Leningrad, 1-106 (in Russian).

Putrya, F.S. \& Leontovich, G.E. 1948. To the study of Middle Carboniferous fusulinids from the Saratov Volga region. Bulletin de la Société des naturalistes de Moscou, Geology, 23, 11-45 (in Russian).

Qi, Y.P., Wang, Z.H., Wang, Y., Ueno, K. \& Wang, X.D. 2007. Stop 1: Nashui section. In: Pennsylvanian and Lower Permian Carbonate Successions from Shallow Marine to Slope in South-ern Guizhou. Guide Book for Field Excursion C3 of the XVI International Congress on the Carboniferous and Permian (eds. Wang, Y., Ueno, K. \& Qi, Y.P.). Nanjing Institute of Geology and Palaeontology, Nanjing, 8-16.

Qi, Y.P., Lambert, L.L., Nemyrovska, T.I., Wang, X.D., Hu, K.Y. \& Wang, Q.L. 2013. Multiple transitional conodont morphologies demonstrate depositional continuity in the Bashkirian-Moscovian boundary interval, Naqing Section, Guizhou, South China. In: The Carboniferous-Permian Transition (eds. Lucas, S.G., DiMichele, W.A., Barrick, J.E., Schneider, J.W. \& Spielmann, J.A.). New Mexico Museum of Natural History and Science Bulletin, 60, 329-336.

Qi, Y.P., Lambert, L.L., Nemyrovska, T.I., Wang, X.D., Hu, K.Y. \& Wang, Q.L. 2016. Late Bashkirian and early Moscovian conodonts from the Naqing section, Luodian, Guizhou, South China. Palaeoworld, 25, 170-187.

Rauzer-Chernousova, D.M. 1938. The upper Paleozoic foraminifera of theSamara Bend and Trans-Volga region. Akademiya Nauk SSSR, Geologich-eskii Institut, Trudy, 7, 69-167 (in Russian).

Rauzer-Chernousova, D.M., Beljaev, G., Reitlinger, E.A., 1936. Verkhnepaleozoiskie foraminifery Petchorskogo kraya [Upper Paleozoic foraminifera of the Petchora area]. Akad. Nauk SSSR, Trudy Poliyarnoi Komissii, 28,159-232 (in Russian with German summary).

Resolutions. 1990. Carboniferous (Kamennougol'naya sistema). In: Resheniye Mezhvedomstvennogo regionalnogo stratigraficheskogo soveshchaniya po srednemy $i$ verkhnemu paleozoyu Russkoy Platformy (The decision of the Interagency regional stratigraphic meeting on the middle and upper Paleozoic of the Russian Platform (Leningrad, 1988) with the regional stratigraphic schemes) (eds. Kaharmanov, A.Kh. \& Donakova, L.M.). VSEGEI Publisher, Leningrad, 1-41 (in Russian).

Ritter, S.M. 1986. Taxonomic revision and phylogeny of post-Early Permian crisis bisselli-whitei Zone conodonts with comments on Late Paleozoic diversity. Geologica et Palaeontologica, 20, 139-165

Savage, N.M. \& Barkeley, S.J. 1985. Early to Middle Pennsylvanian conodonts from the Klawak Formation and the Ladrones Limestone, southeastern Alaska. Journal of Paleontology, 59, 1451-1465.

Scomazzon, A.K., Moutinho, L.P., Nascimento, S., Lemos, V.B. \& Matsuda, N.S. 2016. Conodont biostratigraphy and paleoecology of the marine sequence of the Tapajós Group, Early-Middle Pennsylvanian of Amazonas Basin, Brazil. Journal of South American Earth Sciences, 65, 25-42; doi:10.1016/j.jsames.2015.11.004.

Semikhatova, S.V. 1934. Moscovian deposits of Lower and Middle Volga area and position of the Moscovian Stage in general Carboniferous scale of the USSR. Problems of Soviet Geology, 3/8, 73-92 (in Russian).

Semikhatova, S.V. 1941. The Bashkirian Brachiopods, USSR. I. Genus Choristites Fischer. Trudy Paleontologicheskogo Instituta, Moscow, 1-152 (in Russian).

Sungatullina, G.M. 2014. Determination of the BashkirianMoscovian boundary in the Volga region via conodont species Declinognathodus donetzianus Nemirovskaya. Geological Magazine, 151, 299-310; doi:10.1017/ S001675681300112X.

Sutherland, P.K. \& Grayson, Jr. R.C. 1992. Morrowan and Atokan (Pennsylvanian) biostratigraphy in the Ardmore Basin, Oklahoma. In: Recent Advances in Middle 
Carboniferous Biostratigraphy (eds. Sutherland, P.K. \& Manger, W.L.). Norman, Oklahoma Geological Survey, Circular 94, 81-100.

Sweet, W.C. 1988. The Conodonta: Morphology, Taxonomy, Paleoecology, and Evolutionary History of a Long-Extinct Animal Phylum. Oxford University Press, New York.

Ueno, K. \& Nemyrovska, T.I. 2008. Bashkirian-Moscovian (Pennsylvanian/Upper Carboniferous) Boundary in the Donets Basin, Ukraine. Journal of Geography, 117, 919932 (in Japanese).

Wang, Z.H. \& Qi, Y.P. 2003. Upper Carboniferous (Pennsylvanian) conodonts from South Guizhou of
China. Rivista Italiana di Paleontologia e Stratigrafia, 109, 379-397.

Wang, Z.H., Qi, Y.P., Wang, X.D. \& Wang, Y.J. 2004. Restudy of the Upper Carboniferous (Pennsylvanian) strata from Nashui of Luodian, Guizhou. Acta Micropalaeontologica Sinica, 21, 111-129 (in Chinese with English abstract).

Work, D.M., Mason, C.E. \& Boardman, D.R. 2012. Pennsylvanian (Atokan) Ammonoids from the Magoffin Member of the Four Corners Formation, Eastern Kentucky. Journal of Paleontology, 83, 403-416. 